Prepared in cooperation with the South Carolina Department of Health and Environmental Control

\title{
Low-Flow Frequency and Flow Duration of Selected South Carolina Streams in the Catawba-Wateree and Santee River Basins through March 2012
}

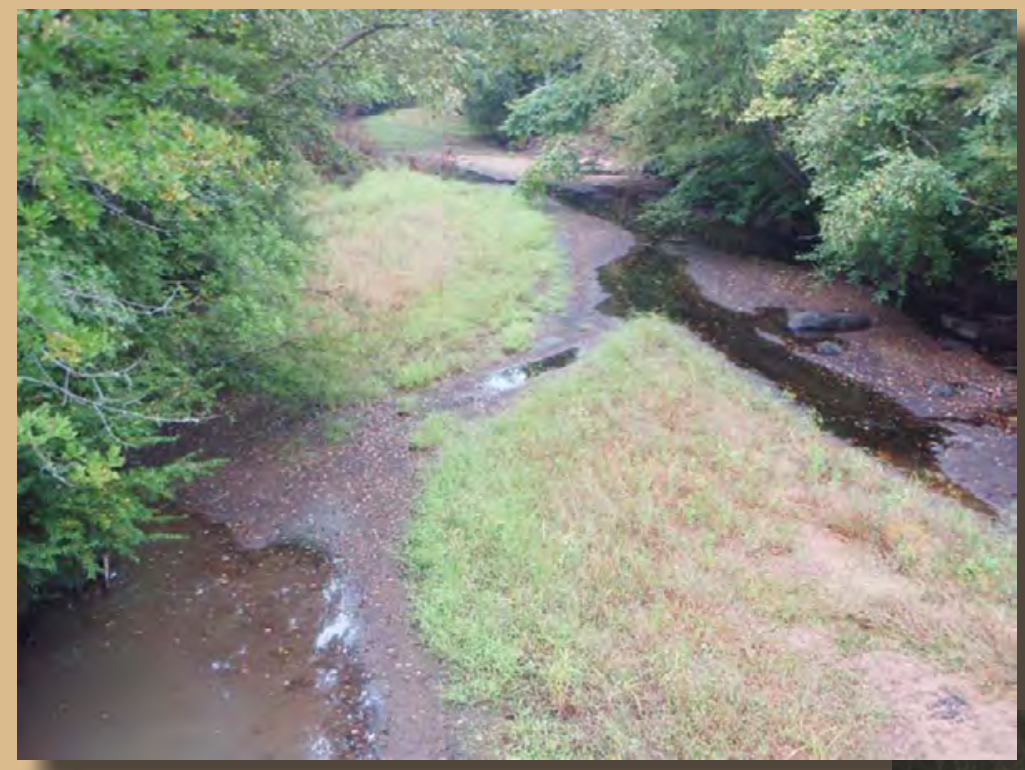

Open-File Report 2014-1113

U.S. Department of the Interior

U.S. Geological Survey 
Cover: Rocky Creek at Great Falls, South Carolina, taken on September 21, 2011. 


\section{Low-Flow Frequency and Flow Duration of Selected South Carolina Streams in the Catawba-Wateree and Santee River Basins through March 2012}

By Toby D. Feaster and Wladmir B. Guimaraes

Prepared in cooperation with the South Carolina Department of Health and Environmental Control

Open-File Report 2014-1113 


\title{
U.S. Department of the Interior SALLY JEWELL, Secretary
}

\author{
U.S. Geological Survey \\ Suzette M. Kimball, Acting Director
}

U.S. Geological Survey, Reston, Virginia: 2014

For more information on the USGS - the Federal source for science about the Earth, its natural and living resources, natural hazards, and the environment, visit http://Www.usgs.gov or call 1-888-ASK-USGS.

For an overview of USGS information products, including maps, imagery, and publications, visit $h t t p: / / w w w . u s g s . g o v / p u b p r o d$

To order this and other USGS information products, visit http://store.usgs.gov

Any use of trade, product, or firm names is for descriptive purposes only and does not imply endorsement by the U.S. Government.

Although this report is in the public domain, permission must be secured from the individual copyright owners to reproduce any copyrighted materials contained within this report.

Suggested citation:

Feaster, T.D., and Guimaraes, W.B., 2014, Low-flow frequency and flow duration of selected South Carolina streams in the Catawba-Wateree and Santee River Basins through March 2012: U.S. Geological Survey Open-File Report 2014-1113, 34 p., http://dx.doi.org/10.3133/ofr20141113.

ISSN 2331-1258 (online) 


\section{Contents}

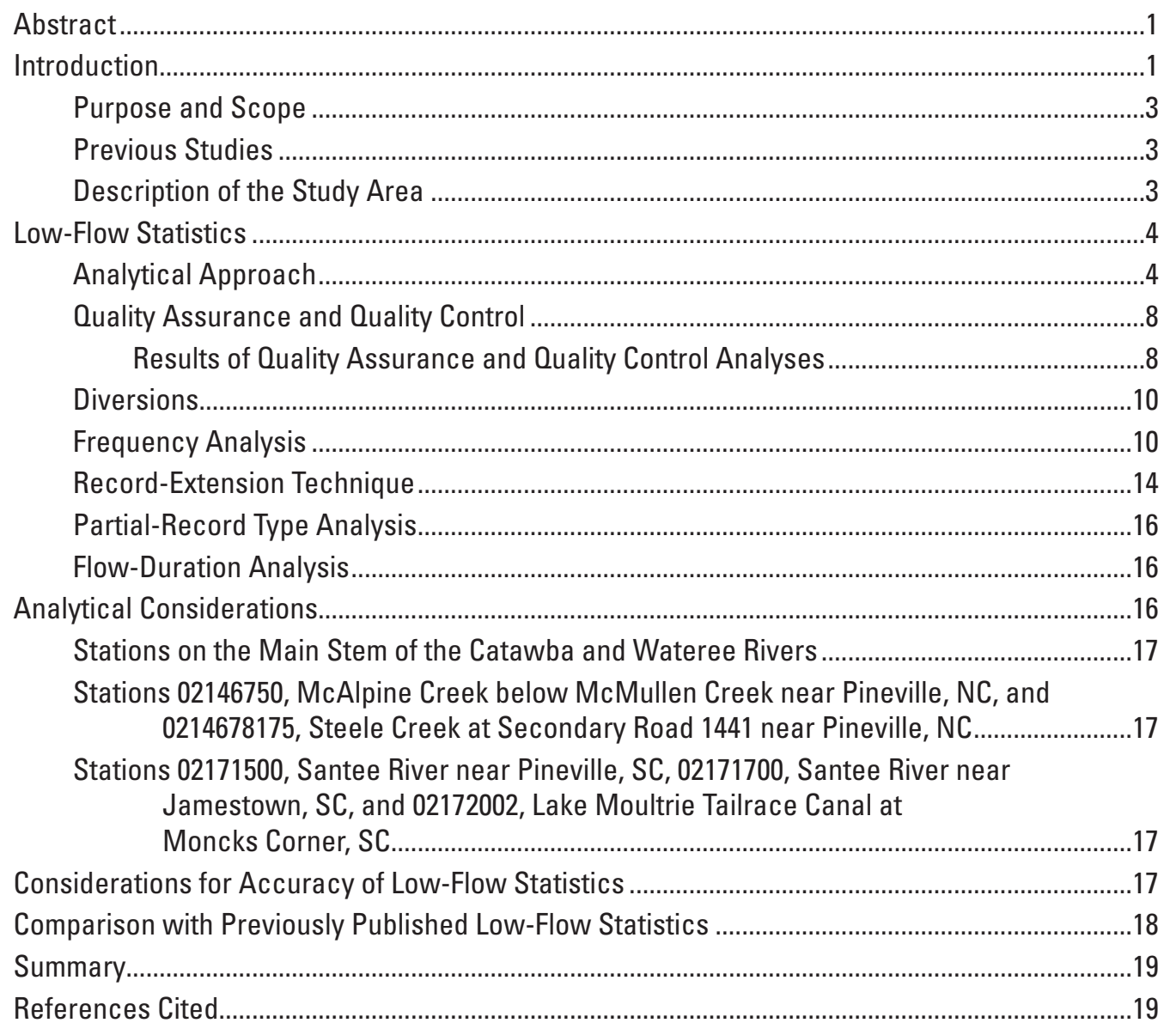




\section{Figures}

1. Map showing the eight major river basins in South Carolina as defined by the South Carolina Department of Health and Environmental Control.

2. Streamgaging stations in the Catawba-Wateree and Santee River Basins of South Carolina, as well as the physiographic provinces, and 8-digit hydrologic-unit code boundaries.

3. Annual minimum 7-day average streamflow at unregulated U.S. Geological

Survey streamgaging stations analyzed in this investigation: 02146750,

McAlpine Creek below McMullen Creek near Pineville, NC; 0214678175,

Steele Creek at Secondary Road 1441 near Pineville, NC; 02147500,

Rocky Creek at Great Falls, SC; and 02148300, Colonels Creek

near Leesburg, SC

4. Annual minimum 7-day average streamflow at regulated U.S. Geological Survey streamgaging stations in South Carolina: 02146000, Catawba River near Rock Hill; 02147020, Catawba River below Catawba; 02148000, Wateree River near Camden; 02148315, Wateree River below Eastover; 02171500, Santee River near Pineville; 02171700, Santee River near Jamestown; and 02172002, Lake Moultrie Tailrace Canal at Moncks Corner.

5. Ratio of median weekday to median 7-day weekly streamflow and the median weekend to median 7-day weekly streamflow at U.S. Geological Survey streamgaging stations 02146000, Catawba River near Rock Hill, SC, and 02148000, Wateree River near Camden, SC.

6. Low-flow frequency curve for the annual minimum 7-day average streamflow for the U.S. Geological Survey streamgaging station 02146750, McAlpine Creek below McMullen Creek near Pineville, NC.

7. Flow-duration curves for U.S. Geological Survey South Carolina streamgaging stations 02148300, Colonels Creek near Leesburg, SC, 02135300, Scape Ore Swamp near Bishopville, SC, and 02169570, Gills Creek at Columbia, SC, for the concurrent period from July 26, 1968, to September 30,1980, in cubic feet per second and cubic feet per second per square mile.

\section{Tables}

1. South Carolina Department of Health and Environmental Control (SCDHEC) schedule for basin data analysis and statistics availability.

2. Low-flow statistics for continuous-record streamgaging stations in the Catawba, Wateree, and Santee River Basins of South Carolina.....

3. Eight-digit hydrologic unit code subbasins, subbasin name, drainage area in South Carolina, and number of U.S. Geological Survey continuous-record streamgaging stations analyzed for the Catawba-Wateree and Santee River Basins of South Carolina

4. Streamgaging stations in the Catawba-Wateree and Santee River Basins of South Carolina that were considered for computations of low-flow statistics

5. Differences between the annual minimum 7-day average streamflow with a 10-year recurrence interval in this report and previously published values for continuous-record streamgaging stations in the Catawba-Wateree and Santee River Basins of South Carolina. 


\section{Conversion Factors}

\begin{tabular}{|c|c|c|}
\hline Multiply & By & To obtain \\
\hline \multicolumn{3}{|c|}{ Length } \\
\hline foot $(\mathrm{ft})$ & 0.3048 & meter $(\mathrm{m})$ \\
\hline mile (mi) & 1.609 & kilometer (km) \\
\hline \multicolumn{3}{|c|}{ Area } \\
\hline square mile $\left(\mathrm{mi}^{2}\right)$ & 2.590 & square kilometer $\left(\mathrm{km}^{2}\right)$ \\
\hline \multicolumn{3}{|c|}{ Volume } \\
\hline cubic foot $\left(\mathrm{ft}^{3}\right)$ & 0.02832 & cubic meter $\left(\mathrm{m}^{3}\right)$ \\
\hline \multicolumn{3}{|c|}{ Flow rate } \\
\hline cubic foot per second $\left(\mathrm{ft}^{3} / \mathrm{s}\right)$ & 0.02832 & cubic meter per second $\left(\mathrm{m}^{3} / \mathrm{s}\right)$ \\
\hline million gallons per day (Mgal/d) & 0.04381 & cubic meter per second $\left(\mathrm{m}^{3} / \mathrm{s}\right)$ \\
\hline
\end{tabular}

Vertical coordinate information is referenced to the National Geodetic Vertical Datum of 1929 (NGVD 29).

Horizontal coordinate information is referenced to the North American Datum of 1927 (NAD 27) or 1983 (NAD 83). 


\section{Abbreviations}

$\begin{array}{ll}\text { CR } & \text { Continuous record } \\ \text { HUC } & \text { Hydrologic unit code } \\ \text { loratio } & \text { Ratio of the 10th percentile to the 50th percentile of the average 7-day flows } \\ \text { MOVE.1 } & \text { Maintenance of Variance Extension, Type 1 } \\ \text { NCDENR } & \text { North Carolina Department of Environment and Natural Resources } \\ \text { NPDES } & \text { National Pollutant Discharge Elimination System } \\ \text { PR } & \text { Partial record } \\ \text { 07 }{ }_{\text {min }} & \text { Annual minimum 7-day average streamflow } \\ \text { QA0C } & \text { Quality assurance and quality control } \\ \text { SCDNR } & \text { South Carolina Department of Natural Resources } \\ \text { SCDHEC } & \text { South Carolina Department of Health and Environmental Control } \\ \text { TMDL } & \text { Total maximum daily load } \\ \text { USGS } & \text { U.S. Geological Survey } \\ \text { WW0MS } & \text { Watershed Water Quality Management Strategy } \\ \text { 702 } & \text { Annual minimum 7-day average streamflow with a 2-year recurrence interval } \\ 7010 & \text { Annual minimum 7-day average streamflow with a 10-year recurrence interval }\end{array}$




\title{
Low-Flow Frequency and Flow Duration of Selected South Carolina Streams in the Catawba-Wateree and Santee River Basins through March 2012
}

\author{
By Toby D. Feaster and Wladmir B. Guimaraes
}

\section{Abstract}

Part of the mission of both the South Carolina Department of Health and Environmental Control and the South Carolina Department of Natural Resources is to protect and preserve South Carolina's water resources. Doing so requires an ongoing understanding of streamflow characteristics of the rivers and streams in South Carolina. A particular need is information concerning the low-flow characteristics of streams, which is especially important for effectively managing the State's water resources during critical flow periods, such as during the historic droughts that South Carolina has experienced in the past few decades.

In 2008, the U.S. Geological Survey, in cooperation with the South Carolina Department of Health and Environmental Control, initiated a study to update low-flow statistics at continuous-record streamgaging stations operated by the U.S. Geological Survey in South Carolina. This report presents the low-flow statistics for 11 selected streamgaging stations in the Catawba-Wateree and Santee River Basins in South Carolina and 2 in North Carolina. For five of the streamgaging stations, low-flow statistics include daily mean flow durations for the 5-, 10-, 25-, 50-, 75-, 90-, and 95-percent probability of exceedance and the annual minimum 1-, 3-, 7-, 14-, 30-, 60-, and 90-day mean flows with recurrence intervals of 2, 5, 10,20,30, and 50 years, depending on the length of record available at the streamgaging station. For the other eight streamgaging stations, only daily mean flow durations and (or) exceedance percentiles of annual minimum 7-day average flows are provided due to regulation. In either case, the low-flow statistics were computed from records available through March 31, 2012.

Of the five streamgaging stations for which recurrence interval computations were made, three streamgaging stations in South Carolina were compared to low-flow statistics that were published in previous U.S. Geological Survey reports. A comparison of the low-flow statistics for the annual minimum 7-day average streamflow with a 10 -year recurrence interval $(7 \mathrm{Q} 10)$ from this study with the most recently published values indicated that two of the streamgaging stations had values lower than the previous values and the $7 \mathrm{Q} 10$ for the third station remained unchanged at zero. Low-flow statistics are influenced by length of record, hydrologic regime under which the data were collected, analytical techniques used, and other factors, such as urbanization, diversions, and droughts that may have occurred in the basin.

\section{Introduction}

Low-flow stream statistics are used by South Carolina State agencies, such as the South Carolina Department of Health and Environmental Control (SCDHEC) and the South Carolina Department of Natural Resources (SCDNR), for many applications, including determining waste-load allocations for point sources, development of total maximum daily loads (TMDLs) for streams, determining the quantity of water that can be withdrawn safely from a particular stream, and preparing the State Water Plan. In addition, low-flow statistics are useful for improving the general level of understanding of natural and regulated stream systems. The droughts of the past few decades in South Carolina (South Carolina Department of Natural Resources, 2013) have heightened awareness of the importance of having up-todate statistics for making critical water-resources decisions.

Because of the importance of these applications, it is critical to effectively measure and document stream base-flow data for use in updating low-flow statistics on a regular basis, preferably about every 10 years. Low-flow statistics, as defined in this report, are annual minimum daily mean streamflow averaged over designated time periods (Riggs, 1972). The use of "average" with respect to the low-flow statistics in this report refers to the arithmetic mean. Low-flow statistics for streams in South Carolina have not been updated in a systematic way since 1987. In 2008, the U.S. Geological Survey (USGS), in cooperation with the SCDHEC, initiated a study to update low-flow statistics at continuous-record streamgaging stations (hereafter referred to as stations in this report) operated by the USGS in South Carolina. The investigation was originally planned (2008) for a period of 5 years to coincide with the SCDHEC Watershed Water Quality Management Strategy (WWQMS) for monitoring and assessment of eight major river basins in South Carolina (fig. 1), which is completed every 5 years (South Carolina Department of Health and Environmental Control, 2009; table 1). However, in 2010, the schedule for updating the low-flow statistics was modified at the request of the SCDHEC. The remaining basins will now be assessed by the USGS on a two-year schedule, and the results will be published during the second year (table 1). 


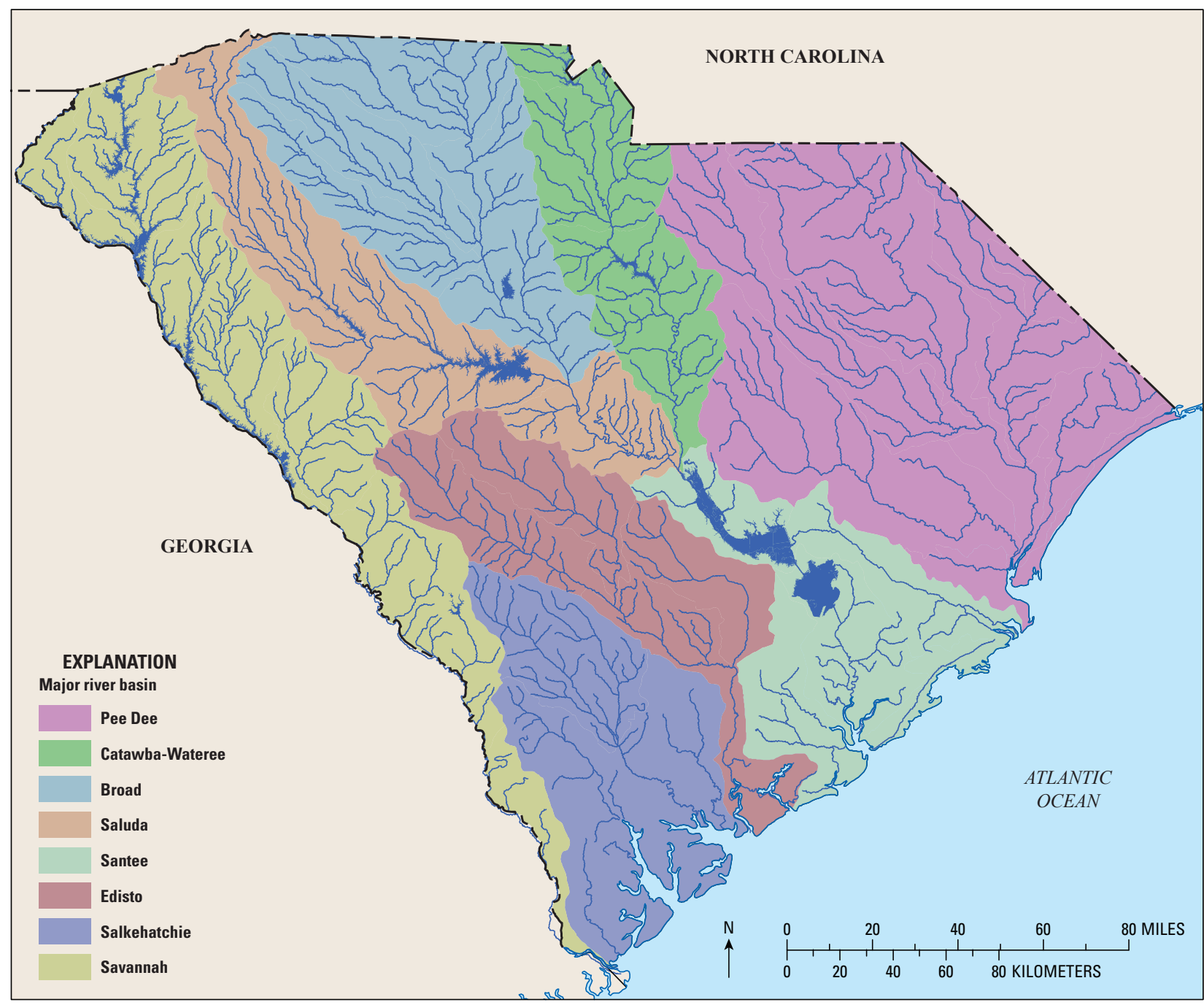

Base from 1:500,000-scale hydrography dataset

and 1:250,000-scale watershed boundary dataset

Albers Equal Area projection; central meridian -960000 ;

rotation angle -8.5; datum NAD 27

Figure 1. The eight major river basins in South Carolina as defined by the South Carolina Department of Health and Environmental Control.

Table 1. South Carolina Department of Health and Environmental Control (SCDHEC) schedule for basin data analysis and statistics availability.

\begin{tabular}{lcc}
\hline \multicolumn{1}{c}{$\begin{array}{c}\text { SCDHEC basin name } \\
\text { (fig. 1) }\end{array}$} & $\begin{array}{c}\text { Data analysis, } \\
\text { year }^{1}\end{array}$ & $\begin{array}{c}\text { Low-flow information } \\
\text { available, year }\end{array}$ \\
\hline Pee Dee & 2008 & 2009 \\
Broad & 2009 & 2010 \\
Saluda and Edisto & 2010 and 2011 & 2012 \\
Catawba-Wateree and Santee & 2012 and 2013 & 2014 \\
Savannah and Salkehatchie & 2014 and 2015 & 2016 \\
\hline
\end{tabular}

${ }^{1}$ The year is the Federal fiscal year, which begins on October 1 and ends on September 30, and is designated by the calendar year in which the period ends. For example, year 2012 is the 12-month period from October 1, 2011, through September 30, 2012. 


\section{Purpose and Scope}

The purpose of this report is to present updated lowflow statistics at continuous-record (CR) stations in the Catawba-Wateree and Santee River Basins of South Carolina. Depending on the length of record available at the CR stations, the report presents estimates of annual minimum 1-, 3-, 7-, 14-, 30-, 60-, and 90-day average streamflows with recurrence intervals of 2, 5, 10, 20,30, and 50 years. Low-flow statistics are presented for 4 of the 11 selected CR stations in the two basins. In addition, daily flow durations for the 5-, 10-, 25-, 50-, 75-, 90-, and 95-percent probabilities of exceedance are presented for these stations (table 2, p. 22). For seven CR stations located on regulated streams, only daily flow durations and (or) exceedance percentiles of annual minimum 7-day average flow are presented.

The scope of this report includes unregulated and regulated streams in the Catawba-Wateree and Santee River Basins of South Carolina. In order for the low-flow statistics to be updated for CR stations included in the previous study (Zalants, 1991a, 1991b), at least 3 years of additional streamflow data had to be collected after 1987. Of the new CR stations for which data were collected after 1987, only the stations that had at least 5 years of data were included.

Daily mean streamflow data for this study were collected through March 31, 2012, which is the end of the 2011 climatic year. The climatic year is a continuous 12-month period during which a complete annual cycle occurs and is arbitrarily selected for the presentation or analysis of data relative to hydrologic or meteorological phenomena (Langbein and Iseri, 1983). The climatic year is usually designated by the calendar year during which most of the 12 months occur. For this investigation, the climatic year is the 12-month period from April 1 through March 31 and is designated by the year in which the period begins. For example, the 2011 climatic year is the period from April 1, 2011, through March 31, 2012. In South Carolina, minimum streamflows typically occur in the fall months (September, October, and November) and, therefore, use of the climatic year, as defined, prevents the annual low-flow cycle from being artificially placed in separate years.

\section{Previous Studies}

Previous reports by Stallings (1967), Johnson and others (1968), Bloxham and others (1970), Bloxham (1976, 1979, 1981), Barker (1986), Zalants (1991a, b), Feaster and Guimaraes $(2009,2012)$, and Guimaraes and Feaster (2010) described the low-flow frequency and flow-duration streamflows for selected CR stations in South Carolina.

Stallings (1967) presented low-flow statistics for 61 CR stations and 83 other sites where flow was measured during the 1954 drought. Johnson and others (1968) focused on the low-flow statistics of streams in Pickens County. Low-flow streamflow measurements from 1945 through 1967 were presented for 32 partial-record (PR) stations. The PR stations were correlated with four index stations to estimate annual minimum 7-day average streamflow with 2-and 10-year recurrence intervals (7Q2 and 7Q10, respectively).

Bloxham and others (1970) presented magnitude and frequency of low-flow streamflows for 9 CR stations in Spartanburg County, and streamflow measurements were presented for 63 sites. At 35 of the 63 sites, correlation methods were used with index stations to estimate the 7Q2 and 7Q10. Bloxham (1976) used 6 index stations from the upper Coastal Plain Physiographic Province to estimate the 7Q2 and $7 \mathrm{Q} 10$ at $54 \mathrm{PR}$ stations and miscellaneous-measurement sites. Bloxham (1979) used data through the 1976 climatic year to compute low-flow frequency and flow-duration estimates at 71 CR stations in South Carolina.

Bloxham (1981) estimated the 7Q2 and 7Q10 at 113 PR stations in the Piedmont and lower Coastal Plain Provinces of South Carolina. Barker (1986) detailed the establishment of 361 PR stations with measurements made from August 1980 through July 1986. Zalants (1991a) provided estimates of the 7Q2 and 7Q10 at 564 PR stations and 27 CR stations on streams in the Blue Ridge, Piedmont, and upper Coastal Plain Provinces in South Carolina and parts of North Carolina and Georgia. Zalants (1991b) provided estimates of annual minimum 1-, 3-, 7-, 14-, 30-, 60-, and 90-day average streamflows with recurrence intervals of 2 to 50 years, depending on the length of record, for 55 CR stations in South Carolina for which at least 5 years of unregulated daily mean streamflow data were available through the 1986 climatic year.

Feaster and Guimaraes (2009), Guimaraes and Feaster (2010), and Feaster and Guimaraes (2012) presented low-flow statistics for 17, 23, and 25 CR stations in the Pee Dee River, Broad River, and Saluda-Congaree-Edisto River Basins in South Carolina, respectively. Low-flow estimates for the Pee Dee River, Broad River, and Saluda-Congaree-Edisto River Basins were generated using daily mean flow data through the 2006, 2007, and 2008 climatic years, respectively. In addition, daily flow durations of the 5- to 95-percent probabilities of exceedance were presented for most of these stations. Much of the general information for this report was taken directly from Feaster and Guimaraes $(2009,2012)$ and Guimaraes and Feaster (2010).

\section{Description of the Study Area}

The study area for this report includes the CatawbaWateree and Santee River Basins of South Carolina. The basins encompass approximately 6,240 square miles $\left(\mathrm{mi}^{2}\right)$ and include all or part of eight 8-digit (subbasin) hydrologic units (Eidson and others, 2005; fig. 2; table 3).

Although the majority of the Catawba River Basin is located in the Piedmont Province of North and South Carolina, the headwaters of the basin begin in the Blue Ridge Province of North Carolina (fig. 2). In North Carolina, the Catawba River Basin encompasses approximately 3,300 $\mathrm{mi}^{2}$ 
(North Carolina State University, 2013) and flows into South Carolina through Lake Wylie. In South Carolina, the Catawba River Basin encompasses approximately $1,070 \mathrm{mi}^{2}$ and includes drainage from York, Lancaster, Chester, and Fairfield Counties (South Carolina Department of Health and Environmental Control, 2012). Downstream from Lake Wylie, the Catawba River is joined by four major tributaries: Sugar Creek, Twelvemile Creek, Waxhaw Creek, and Cane Creek. Other than Cane Creek, these tributaries predominately drain from North Carolina with Sugar Creek being the most urbanized of the basins with significant drainage from Charlotte, N.C. (Feaster and others, 2003). Land use in the Catawba River Basin is predominantly forest (60 percent) and agriculture (23 percent) with about 14 percent considered to be urban (South Carolina Department of Health and Environmental Control, 2012).

The Wateree River Basin encompasses approximately $1,260 \mathrm{mi}^{2}$ and includes drainage from Fairfield, Kershaw, Richland, Lancaster, and Lee Counties in South Carolina (South Carolina Department of Health and Environmental Control, 2012; fig. 2). Formed by the convergence of Big Wateree Creek and the Catawba River, the Wateree River flows through Lake Wateree, which is the southernmost of 11 major reservoirs located along the Catawba River corridor (Feaster and Conrads, 2000). Approximately 3 miles downstream from the Lake Wateree Dam, the Wateree River crosses the Fall Line, which is the name given the boundary between the Piedmont and upper Coastal Plain Provinces. This boundary is generally characterized by a series of rapids or falls where the streams transition from the more resistant rocks of the Piedmont to the deeper valleys worn into the softer sediments of the Coastal Plain Province (Cooke, 1936). Land use in the Wateree River Basin is predominantly forested land/wetland (72 percent) and agriculture (18 percent) with about 7 percent being considered urban (South Carolina Department of Health and Environmental Control, 2012). The basin includes four major subwatersheds: Grannies Quarter Creek, Sawneys Creek, Twentyfive Mile Creek, and Big Pine Tree Creek.

The Santee River Basin originates at the confluence of the Congaree and Wateree Rivers. The basin begins in the upper Coastal Plain Province but is predominantly located in the lower Coastal Plain Province and encompasses approximately 1,280 $\mathrm{mi}^{2}$. The Santee River Basin includes drainage from eight South Carolina counties: Berkeley, Calhoun, Charleston, Clarendon, Georgetown, Orangeburg, Sumter, and Williamsburg (South Carolina Department of Natural Resources, 2009). Land use in the Santee River Basin is predominantly forested land/ wetland (62 percent) and agriculture (14 percent) with about 11 percent being water (South Carolina Department of Health and Environmental Control, 2005). The Santee River flows directly into Lake Marion. From
1941 to 1985 , most of the flow from Lake Marion (about 80 percent of the long-term average flow of the Santee River) was diverted to the Cooper River through a diversion canal to Lake Moultrie for the purpose of hydroelectric power generation (Patterson and others, 1996; South Carolina Department of Natural Resources, 2009). This diversion of flow had the unintended consequences of substantially increasing sediment in the Charleston Harbor and also altering the salinity characteristics of the lower Santee and Cooper Rivers. To mitigate the sedimentation and salinity problems, a rediversion canal was completed about 1985 , restoring much of the previously diverted flow back to the lower Santee River.

The SCDHEC also includes the Ashley and Cooper River Basins as part of the Santee River Basin (fig. 2). The Cooper River Basin encompasses $843 \mathrm{mi}^{2}$ and is completely contained in the lower Coastal Plain Province. Predominant land-use types include about 67 percent forested lands (wetlands), 16 percent water, and 8 percent urban (South Carolina Department of Health and Environmental Control, 2013). The Ashley River Basin encompasses $894 \mathrm{mi}^{2}$ and also is completely contained in the lower Coastal Plain Province. Predominant land-use types include about 55 percent forested lands (wetlands), 15 percent nonforested wetland, 10 percent urban, and 9 percent water.

\section{Low-Flow Statistics}

Hydrologic information on the availability of streamflow under low-flow conditions is essential for the effective management of water resources. Low-flow statistics that define the magnitude and frequency of low-flow events typically are provided as a minimum average streamflow over some designated time period at a streamgaging location. For example, one of the most common low-flow statistics is the annual minimum 7-day average streamflow with a 10 -year recurrence interval (7Q10). In terms of probability of occurrence, there is a one-tenth or 10-percent probability that the annual minimum 7-day average streamflow in any single year will be equal to or less than the estimated 7Q10 value for a specific location (Riggs, 1985).

\section{Analytical Approach}

The analyses of CR stations included in this study were based on four categories of stations: (1) long-term record stations; (2) short-term record stations that have at least 10 years of record; (3) stations that have between 5 and 10 years of record, which were analyzed for a limited set of low-flow statistics by using techniques typically used in analyzing PR stations; and (4) regulated stations. 


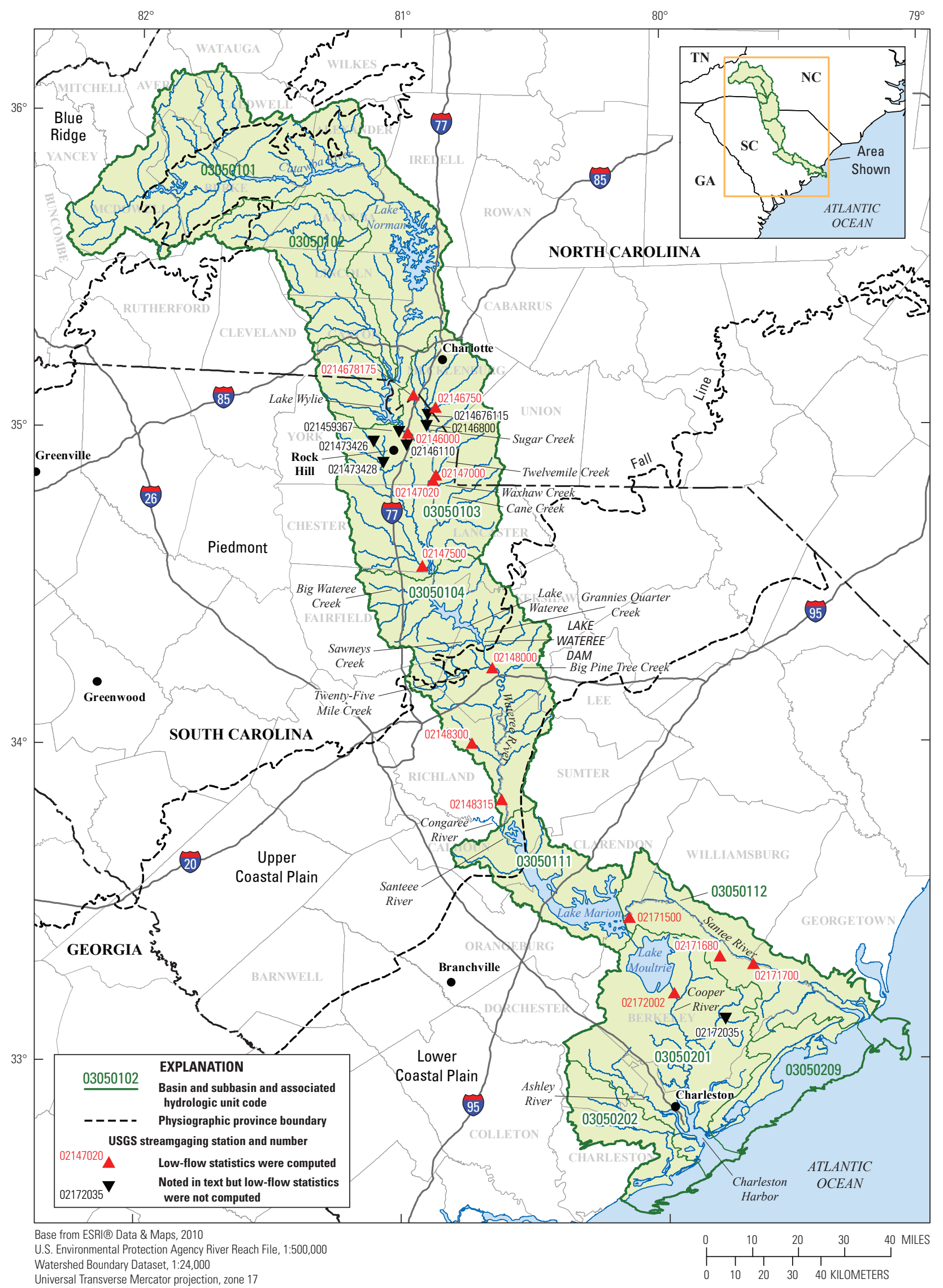

Figure 2. Streamgaging stations in the Catawba-Wateree and Santee River Basins of South Carolina, as well as the physiographic provinces, and 8-digit hydrologic-unit code boundaries. 
Table 3. Eight-digit hydrologic unit code subbasins, subbasin name, drainage area in South Carolina, and number of U.S. Geological Survey continuous-record streamgaging stations analyzed for the Catawba-Wateree and Santee River Basins of South Carolina.

[HUC, hydrologic unit code; $\mathrm{mi}^{2}$, square mile; USGS, U.S. Geological Survey; Subbasins in bold text are wholly contained in South Carolina]

\begin{tabular}{clcc}
\hline $\begin{array}{c}\text { Eight-digit } \\
\text { (subbasin) } \\
\text { HUC number } \\
\text { (fig. 2) }\end{array}$ & $\begin{array}{c}\text { Subbasin } \\
\text { name }\end{array}$ & $\begin{array}{c}\text { Drainage area } \\
\text { in South Caro- } \\
\text { lina, in } \mathbf{~ m i}^{2}\end{array}$ & $\begin{array}{c}\text { USGS } \\
\text { continuous- } \\
\text { record } \\
\text { streamgag- } \\
\text { ing stations } \\
\text { analyzed }\end{array}$ \\
\hline 03050101 & Upper Catawba & 191 & 0 \\
03050103 & Lower Catawba & 1,360 & 5 \\
$\mathbf{0 3 0 5 0 1 0 4}$ & Wateree & $\mathbf{1 , 2 6 0}$ & $\mathbf{3}$ \\
$\mathbf{0 3 0 5 0 1 1 1}$ & Lake Marion & $\mathbf{5 4 8}$ & $\mathbf{0}$ \\
$\mathbf{0 3 0 5 0 1 1 2}$ & Santee & $\mathbf{7 6 1}$ & $\mathbf{2}$ \\
$\mathbf{0 3 0 5 0 2 0 1}$ & Cooper & $\mathbf{1 , 2 6 0}$ & $\mathbf{1}$ \\
$\mathbf{0 3 0 5 0 2 0 2}$ & Stono & $\mathbf{3 8 9}$ & $\mathbf{0}$ \\
$\mathbf{0 3 0 5 0 2 0 9}$ & Bulls Bay & $\mathbf{4 6 8}$ & $\mathbf{0}$ \\
\hline Total & & 6,240 & 11 \\
\hline
\end{tabular}

Typically, low-flow statistics are computed at CR stations if at least 10 years of record are available; however, computing low-flow statistics from long-term records is preferred because the long-term records are considered to be more representative of a broad range of hydrologic conditions. Thus, long-term streamgaging data are better suited for trend assessments and statistical estimates. The USGS uses a value of 30 years of streamflow record to designate long-term streamgages (U.S. Geological Survey, 2013b).

For CR stations with short-term records (those which have at least 10 years of record but less than about 30 years, representing the second category of stations), the lowflow statistics can possibly be improved by using record extension or augmentation methods (Hirsch, 1982) based on correlations with long-term stations. This approach is particularly beneficial if the streamflow data at the shortterm record station were collected during an unusually dry, wet, or otherwise unrepresentative period. As a result, the record-extension techniques allow a more representative range of low-flow conditions at the site. If two long-term record stations are located on the same stream and one of the stations has many more years of record that includes different hydrologic conditions, it also may be beneficial to extend the long-term record station that has the least years of record. There were no stations in the Catawba-Wateree and Santee River basins for which extensions of short-term or long-term stations were applied.

A standard PR station is a site where limited streamflow data are collected on a systematic basis over a period of years for use in hydrologic analyses. For low-flow analyses, typically 10 to 20 base-flow measurements are made over a period of several years. Then, mathematical or graphical techniques are used to correlate the base-flow measurements with concurrent daily mean flows at a CR station (index station; Riggs, 1972; Zalants, 1991a). As noted by Riggs (1972), such a relation can be used to define a limited set of low-flow statistics at the PR station but should not be used to define an entire frequency curve because to do so would imply a greater accuracy than is warranted. Consequently, only the annual minimum 7-day average low-flow statistics with 2- and 10-year recurrence intervals (7Q2 and 7Q10, respectively) usually are estimated at PR stations (U.S. Geological Survey, 1979).

This report and study include only CR stations. As with standard PR stations, however, similar techniques can be used to correlate daily mean flows at CR stations that have more than 5 years but less than 10 years of $C R$ streamgaging data. In Feaster and Guimaraes $(2009,2012)$ and Guimaraes and Feaster (2010), such CR stations were referred to as PR stations and represented a third category of stations that were analyzed. Similar to the analyses at standard PR stations, only the 7Q2 and 7Q10 low-flow statistics were estimated at such CR stations. However, no PR stations were analyzed in the Catawba-Wateree and Santee River Basins because no suitable index stations were found. Index station criteria will be discussed later in the report.

A fourth category of stations included in this study are CR stations on regulated streams. If an assessment of the daily mean flow at a regulated station indicates that the pattern of regulation has been relatively consistent, and if the logarithms of the $N$-day flows (where $N$ is the number of days used to compute the annual minimum average flow) are consistent with a Pearson Type III distribution, low-flow statistics can be computed for that period using similar techniques as is used for the unregulated stations (Riggs, 1972). The techniques used for estimating lowflow statistics at PR sites usually are applicable only to unregulated streams and, therefore, should not be applied to streams that are highly regulated, such as for power generation. In addition, the low-flow statistics for regulated streams are relevant to similar future regulation patterns and would not be applicable if the future regulation patterns were altered significantly. For the Catawba-Wateree and Santee River Basins, none of the regulated stations were considered appropriate for computing low-flow frequency statistics. Consequently, only daily duration flows and (or) exceedance of annual minimum 7-day average flows were computed. Information regarding regulation at applicable CR stations is provided in the "Remarks" sections for stations listed in table 2. All stations considered for computations for low-flow statistics in the Catawba-Wateree and Santee River Basins are listed in table 4 along with the period of record and drainage area. 
Table 4. Streamgaging stations in the Catawba-Wateree and Santee River Basins of South Carolina that were considered for computations of low-flow statistics.

$\left[\mathrm{mi}^{2}\right.$, square miles; $\mathrm{Q} 7_{\min }$, annual minimum 7-day average flow $]$

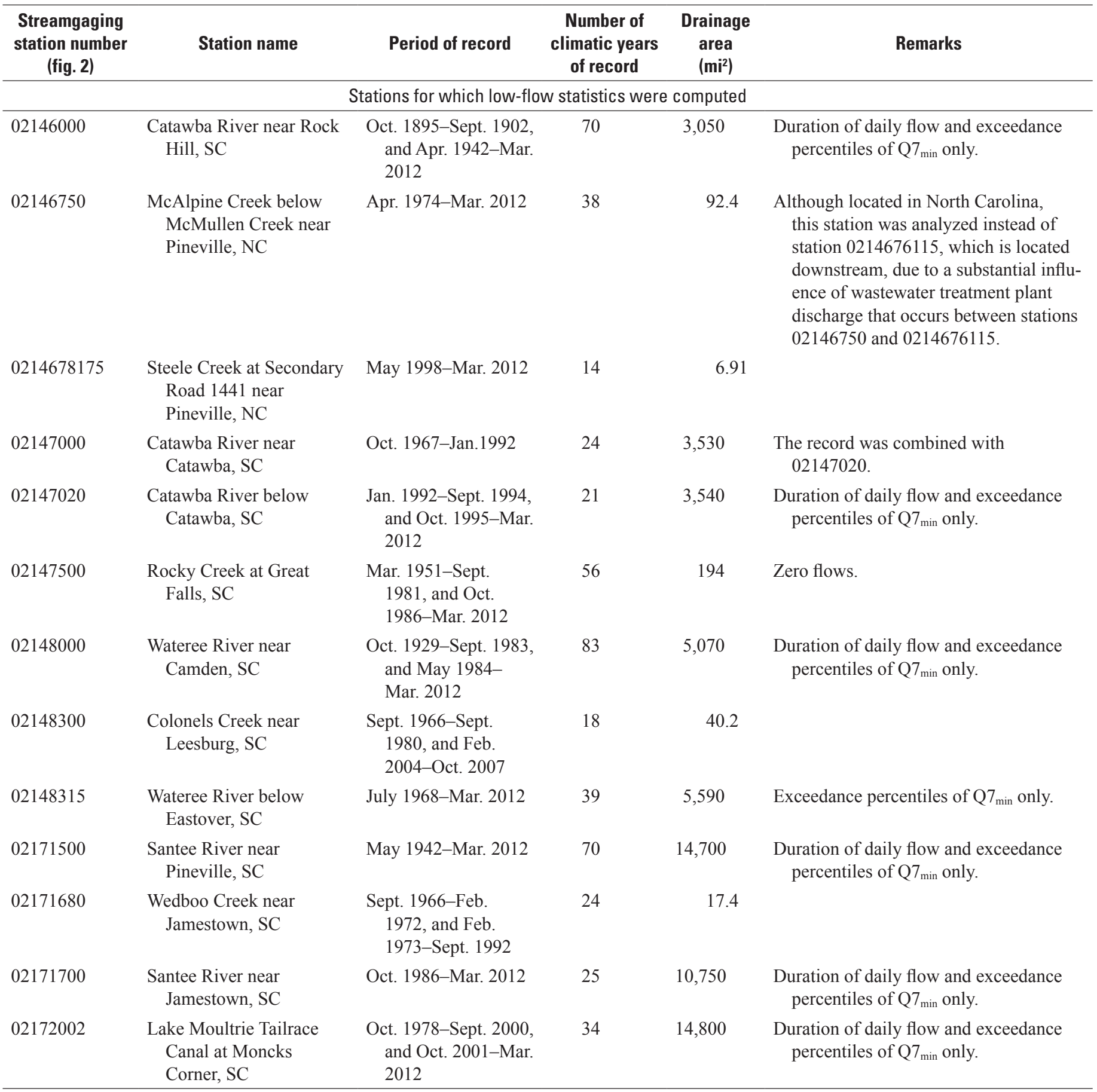




\section{Quality Assurance and Quality Control}

For this study, a quality assurance and quality control (QAQC) analysis was done on the annual minimum 7-day average streamflow data for the CR stations that had a minimum of 10 years of record. The data at each station were reviewed for homogeneity, which implies relatively stable basin conditions during the period of record. The Kendall's tau test was used to assess the homogeneity of the record at each station (Helsel and Hirsch, 1992). The Kendall's tau test provides an independent measure of the monotonic relation between the "X" value (date) and the "Y" value (annual minimum 7-day average streamflow). A null hypothesis is made that the two variables are independent of each other and if the hypothesis is rejected, the independence of the variables is substantiated. A calculated probability value ( $p$-value) estimates the probability of rejecting the null hypothesis. In this study, the independence of the two variables is considered statistically significant when the "p-value" is less than or equal to 0.05 . If a trend (nonhomogeneity) was indicated, additional assessments were used to determine if the trend may have been caused by a short-term condition. For example, if the station record happened to begin or end under extreme conditions (excessively wet or dry), the test may indicate a trend, but additional analysis that excludes the extreme events may indicate no trend. Trends at unregulated stations may result from changes in climatic cycles, land use, groundwater pumping, or other practices that may affect groundwater levels. For stations downstream from a major source of regulation, such as a dam, the data were assessed for gross trends, which may indicate a long-term change in the pattern of regulation (William Kirby, U.S. Geological Survey, written commun., June 6, 2005). Additionally, some investigations have shown that substantial urbanization can lead to a reduction in low flows (U.S. Environmental Protection Agency, 2009). Final decisions to include or exclude data from a specific station analyses were made by using hydrologic judgment based on the results of the QAQC analyses and other available information, such as comparisons with other long-term stations.

The QAQC analyses included the use of several computer programs that were developed by using commercial statistical software (SAS Institute, Inc., 1989). The components of the QAQC reviews that were conducted for the CR stations are as follows:

- Plot of the ratios of median daily mean flows during the weekend (Saturday and Sunday) and entire week (Sunday through Saturday), and work week (Monday through Friday) and entire week against climatic year. These plots are useful for regulated streams and can show if the discharge patterns differ from week days to weekends.

- The Kendall's tau test to check for trends in the annual minimum 7-day average streamflow data over time.
- Plot of the annual minimum 7-day average streamflow against climatic year, which is used along with the Kendall's tau results to assess potential trends.

- Plot of the relation of the ratio of the 10th percentile to the 50th percentile of the average 7-day flows (loratio) against climatic year, which is useful for graphically assessing potential trends.

- Plot of the relation of the 50th percentile of the average 7-day flow against climatic year. This plot is useful for assessing potential changes in the median average 7-day flow over time.

- Plot of the relation of the cumulative loratio against climatic year. A significant change in the slope of this relation indicates a change in flow patterns.

- Plot of the relation of the cumulative 50th percentile of the average 7-day flow against climatic year. A significant change in the slope of this relation indicates changes in the median average 7-day flow patterns.

\section{Results of Quality Assurance and Quality Control Analyses}

A trend analysis, as described previously, was made for all stations in the investigation using a p-value of 0.05 , which is the probability of obtaining the computed test statistic, or one even less likely, when the null hypothesis is true (Helsel and Hirsch, 1992). For the Kendall's Tau trend analysis in this study, the null hypothesis is that there is no trend in the annual minimum 7-day average flow data. For the following unregulated stations, the analyses indicated a trend in the annual minimum 7-day average streamflow for the period of record analyzed: 0214678175 , Steele Creek at Secondary Road 1441 near Pineville, NC; 02147500, Rocky Creek at Great Falls, SC; and 02148300, Colonels Creek near Leesburg, SC. A trend was not indicated at 02146750 , McAlpine Creek below McMullen Creek near Pineville, $\mathrm{NC}$. As can be seen in figure 3, the annual minimum 7-day average flows for the unregulated streamgages have been historically low in recent years as a result of substantial dry periods that have occurred in the Southeast during the last several decades. Consequently, it is likely that these trends are a reflection of these streamgage records ending in these historically dry periods. If these periods are actually part of a short-term hydrologic regime and not reflective of a shift in long-term climatic conditions, when viewed in terms of longer timeframes, the periods may just be part of a much longer term oscillation (Feaster and Guimaraes, 2009, 2012; Guimaraes and Feaster, 2010; Lins and others, 2010). As can be seen at station 02147500, after the historic drought in the 1950 s, the hydrologic regime moved back into a period of more well sustained low flows (fig. 3). 

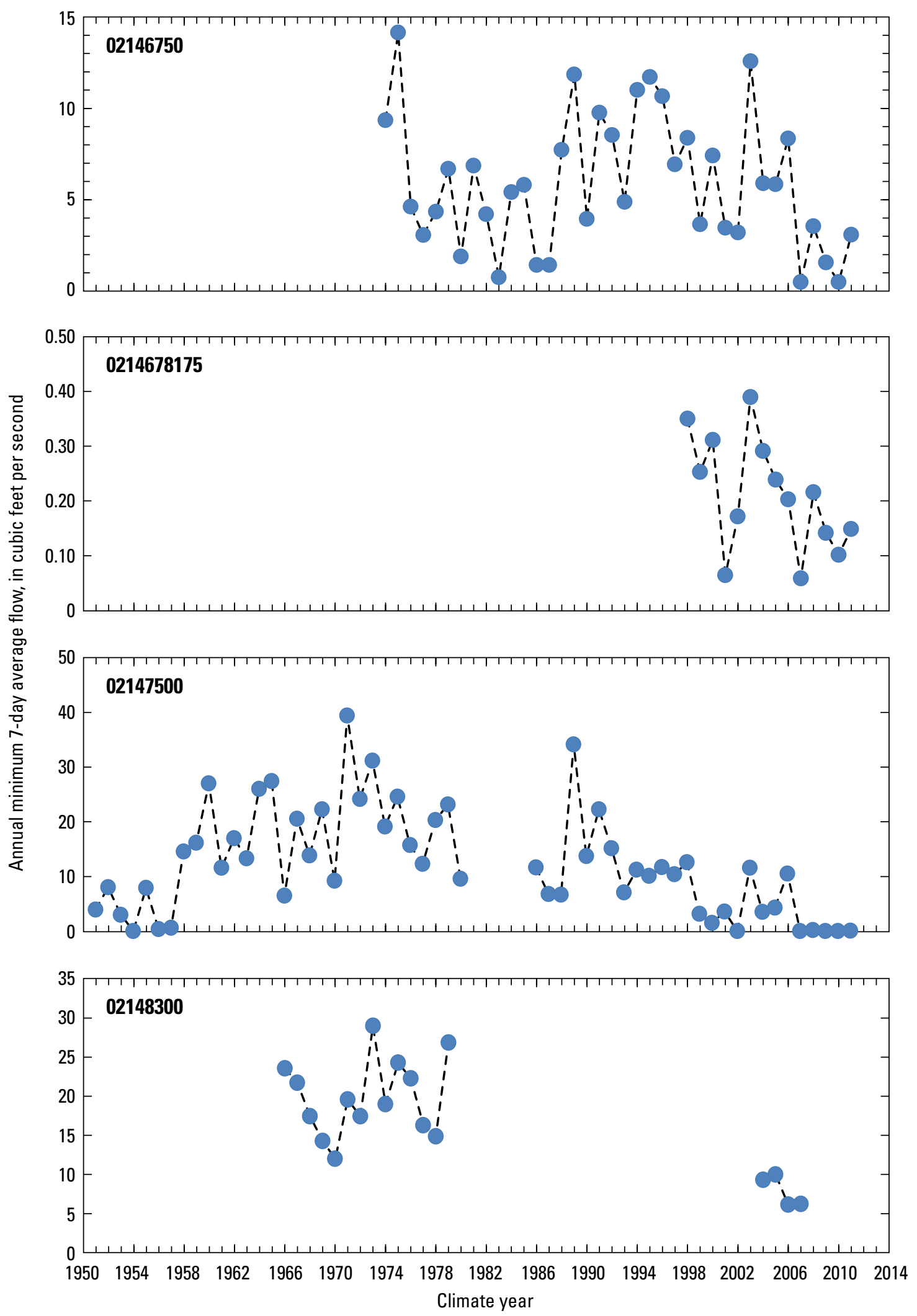

Figure 3. Annual minimum 7-day average streamflow at unregulated U.S. Geological Survey streamgaging stations analyzed in this investigation: 02146750, McAlpine Creek below McMullen Creek near Pineville, NC; 0214678175, Steele Creek at Secondary Road 1441 near Pineville, NC; 02147500, Rocky Creek at Great Falls, SC; and 02148300, Colonels Creek near Leesburg, SC. 
For the regulated streamgages, interpretations of trend analyses are a bit more complicated. Streamflows at regulated stations also are influenced by changes in climatic patterns, but those changes can be mitigated, enhanced, or even offset by changes in regulation patterns. Nonetheless, assessments in the flow patterns are useful to help determine the appropriateness of a frequency analysis at a regulated streamgage. Thus, the trend test also was done for the regulated streamgages. For the following regulated streamgages, no trend was indicated in the annual minimum 7-day average flows: 02146000, Catawba River near Rock Hill, SC; 02147020, Catawba River below Catawba, SC; 02148000 , Wateree River near Camden, SC; 02148315, Wateree River below Eastover, SC; and 02171700, Santee River near Jamestown, SC (fig. 4). Trends were indicated for 02171500, Santee River near Pineville, SC, and 02172002, Lake Moultrie Tailrace Canal at Moncks Corner, SC (fig. 4).

Unlike the unregulated streamgages shown in figure 3 , the regulated streamgages on the Catawba and Wateree River reflect an increase in the annual minimum 7-day average flows in recent years (fig. 4). This increase is likely due to changing regulation patterns associated with minimum flow releases, which is discussed further in the Analytical Considerations section. Additionally, the substantial modifications to the hydrology in the Santee River Basin are reflected in the various flow patterns shown for station 02171500 (fig. 4) and are discussed in that section.

One additional change in regulation patterns reflected in the analysis of streamflow at the longer term streamgages on the Catawba and Wateree Rivers (stations 02146000 and 02148000 , respectively) is the changes that have occurred in regulation patterns between the weekend and weekday flows (fig. $5 A, B$ ). The USGS first reported those variations in a previous investigation relating to water quality on the Wateree River (Feaster and others, 2003). At that time, operators of the hydroelectric plant indicated that no conscious effort had been made to change the weekend flow patterns during the timeframe from the early 1970 s to the early 1990s but that it was likely a reflection of the hydroelectric plants transitioning from a mainly base-load power generation operation to a more varied power generation operation to meet peak energy needs (William Stroud, Duke Energy, written commun., 1998).

\section{Diversions}

Diversions from natural streamflows occur for a variety of reasons. Some diversions are the result of water-supply withdrawals, manufacturing, point-source discharges, and agricultural needs, such as irrigation. Diversions by manufacturers are sometimes confined to short distances along rivers. Water may be taken from the river channel, passed through the manufacturing plant for use in processing, cooling, or dilution of wastes, and then returned to the river. Therefore, in many cases, consumptive losses from diversions by manufacturers may be negligible (Ries, 1994). Thus, the effects of diversions to the streamflow regime of a river are variable and depend not only on where the diversions occur but also on the final outcome of the diverted water.

Ries (1994) noted that water diverted from a stream or adjacent aquifer for municipal supplies is returned to the basin as effluent from individual septic systems or from wastewater- treatment plants within the basin and generally causes little loss of water to the basin; however, such diversions may affect the temporal pattern of streamflows. Diversions from one basin to another reduce streamflow in the donor basin and increase streamflow in the receiving basin. Diversions between subbasins of a larger basin can substantially affect streamflows in the subbasins, but if consumptive losses are negligible, streamflows in the larger basin may be nearly unaffected.

The various diversion scenarios described above indicates that a proper accounting of all diversions in a basin is typically difficult; therefore, most USGS low-flow analyses are made on the flow data as measured at the station without adjustments for diversions. For this study, diversion data, when available, were obtained from the SCDHEC and assessed to determine significance. Diversions upstream from a station were considered significant if the average annual diversion equaled or exceeded 10 percent of the mean annual minimum 1-day streamflow for the period of record. The assumptions for this comparison were that the diversion and streamflow data are of similar quality and were measured with the same frequency and based on concurrent periods of record. If these conditions did not exist, assessments still were made and comments were noted in table 2 regarding the diversions, but no adjustments were made to the low-flow estimates.

\section{Frequency Analysis}

Low-flow frequency statistics at $\mathrm{CR}$ stations are computed by fitting a series of annual minimum $N$-day average streamflows to some known statistical distribution, where $N$ can equal any number from 1 to 365. Low-flow frequency statistics for this study were computed by fitting logarithms (base 10) of the annual minimum 1-, 3-, 7-, 14-, 30-, 60-, and 90-day average streamflows to a Pearson Type III distribution, which also is referred to as a log-Pearson Type III distribution. Fitting the distribution requires calculating the mean, standard deviation, and skew coefficient of the logarithms of the $N$-day streamflows. Estimates of the $N$-day non-exceedance flows for a specified recurrence interval $T$ are computed by using the following equation:

where

$$
\log Q_{T}=\bar{X}+K S
$$

$Q_{T} \quad$ is the $N$-day low flow, in cubic feet per second, and $T$ is the recurrence interval, in years;

$\bar{X} \quad$ is the mean of the logarithms of the annual minimum $N$-day average streamflows;

$K \quad$ is a frequency factor that is a function of the recurrence interval and the coefficient of skew; and

$S \quad$ is the standard deviation of the logarithms of the annual minimum $N$-day average streamflows. 

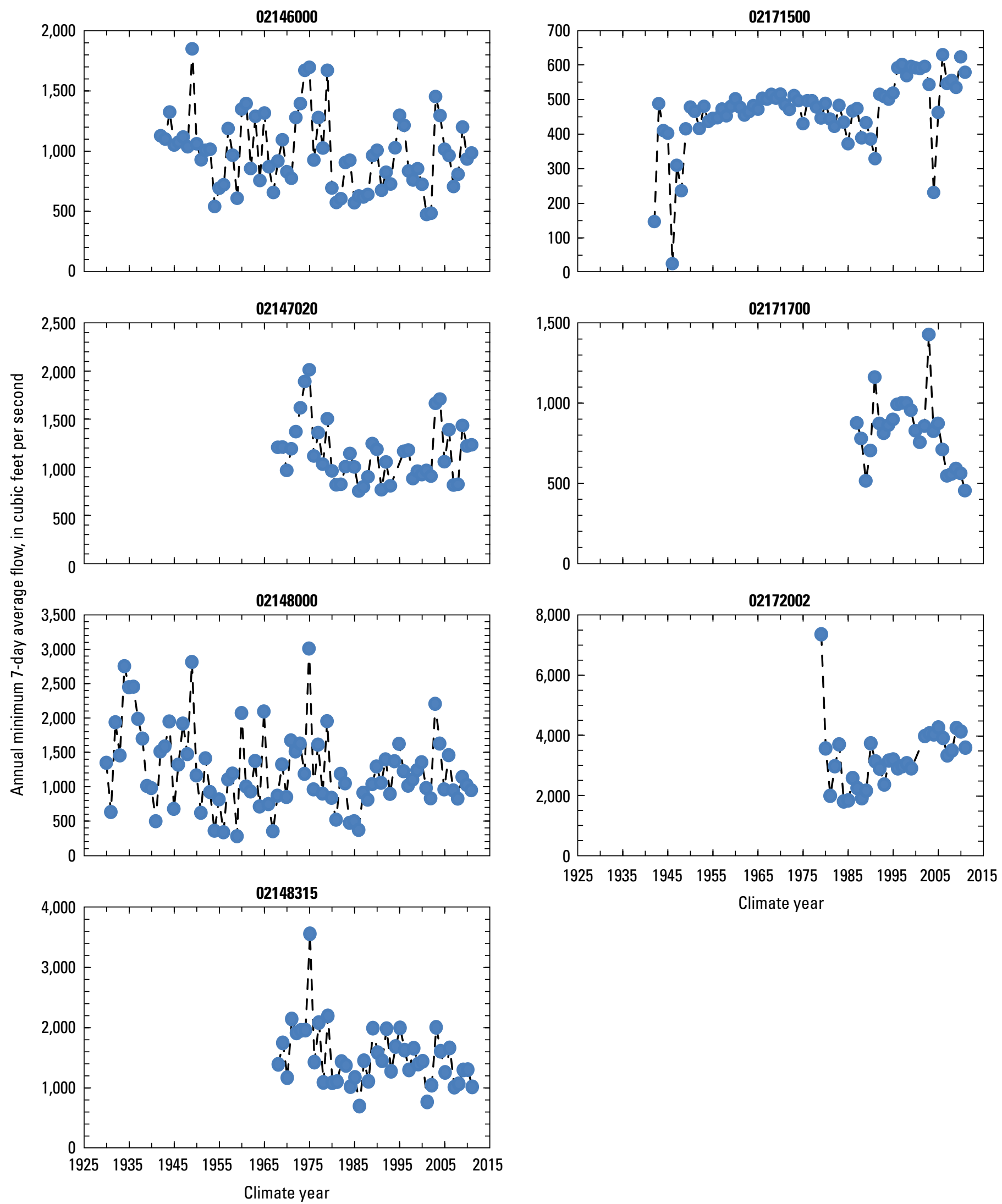

Figure 4. Annual minimum 7-day average streamflow at regulated U.S. Geological Survey streamgaging stations in South Carolina: 02146000, Catawba River near Rock Hill; 02147020, Catawba River below Catawba; 02148000, Wateree River near Camden; 02148315, Wateree River below Eastover; 02171500, Santee River near Pineville; 02171700, Santee River near Jamestown; and 02172002, Lake Moultrie Tailrace Canal at Moncks Corner. 
A. (02146000, Catawba River near Rock Hill, S.C.)

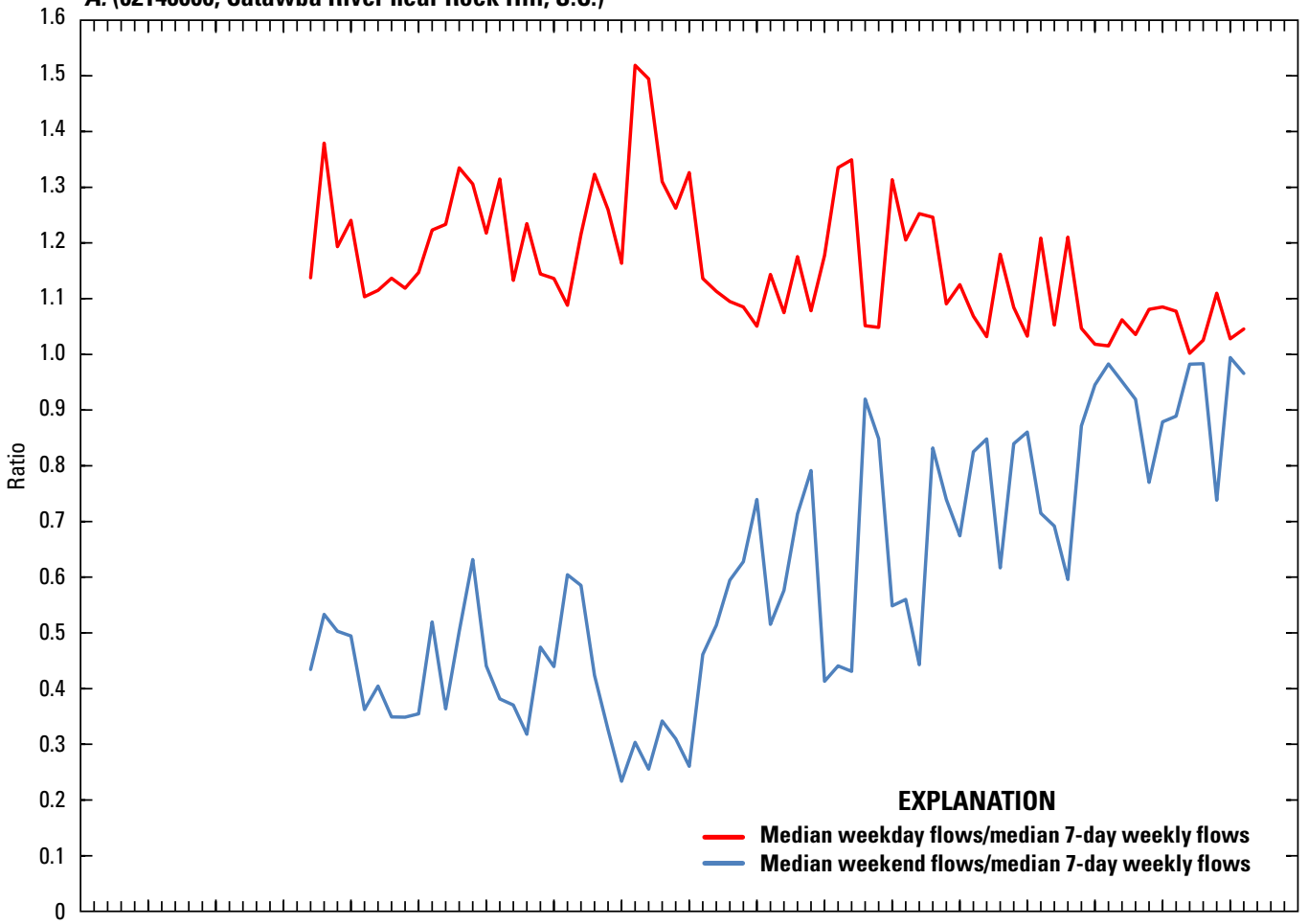

B. (02148000, Wateree River near Camden, S.C.)

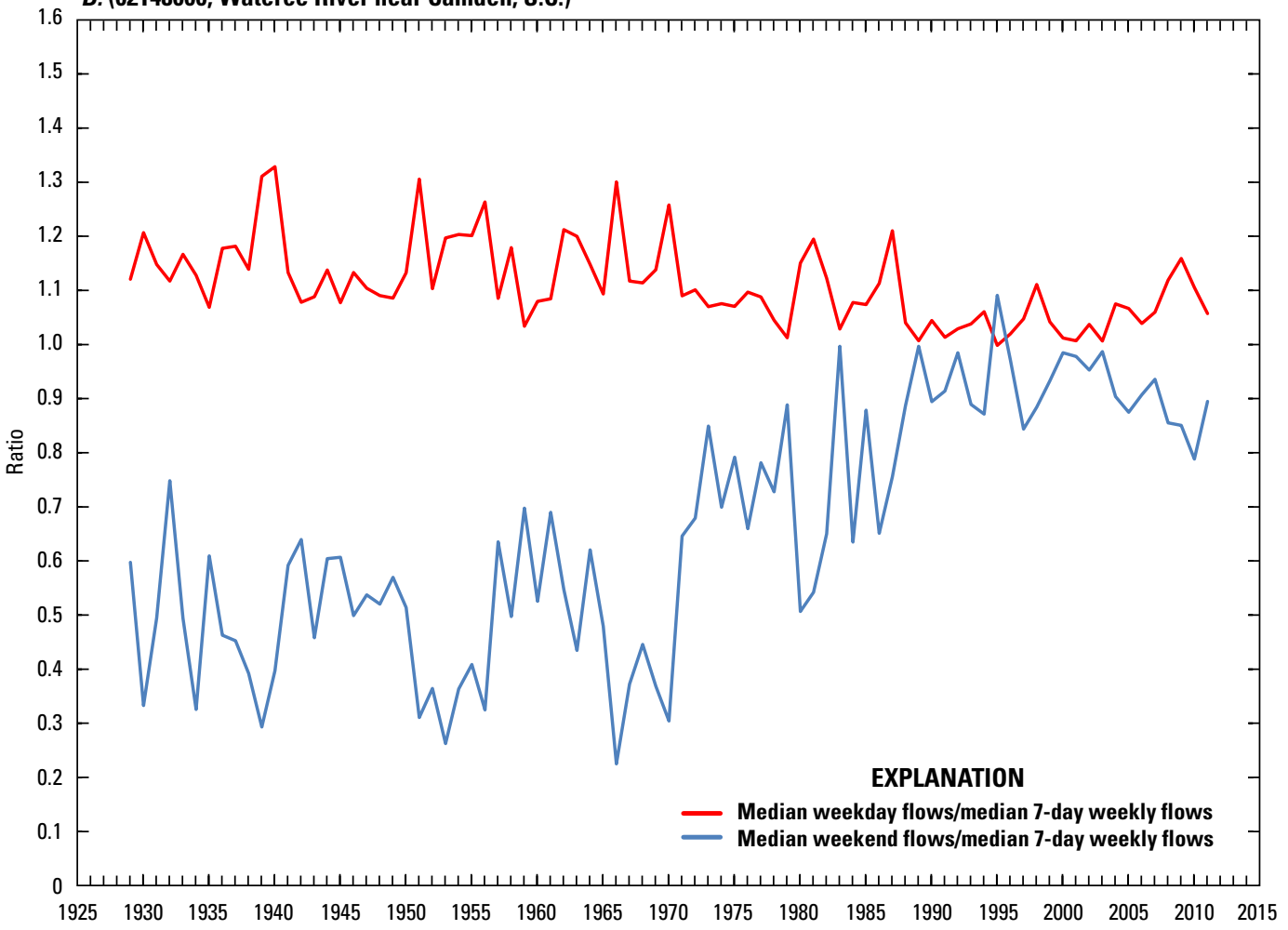

Figure 5. Ratio of median weekday to median 7-day weekly streamflow and the median weekend to median 7-day weekly streamflow at U.S. Geological Survey streamgaging stations $(A) 02146000$, Catawba River near Rock Hill, SC, and $(B)$ 02148000, Wateree River near Camden, SC. 
Low-flow statistics typically are presented as a set of non-exceedance probabilities or, alternatively, recurrence intervals along with the associated low-flow values. The non-exceedance probability is defined as the probability that a flow at a given station will be equal to or less than the associated low-flow value once in a 1-year period and is expressed as a decimal fraction less than 1.0 or as a percentage less than 100 . Recurrence interval is defined as the average interval of years (usually referred to as the return period) during which flows at a given station will be equal to or less than the associated low-flow value once. For example, a low-flow value at a given station with a non-exceedance probability of 0.10 indicates that flows at that station have a 10-percent chance of being equal to or less than the low-flow value once in any given year. Recurrence interval and nonexceedance probability are the mathematical inverses of one another; therefore, a flow with a non-exceedance probability of 0.10 has a recurrence interval of 1 divided by 0.10 or 10 years. It should be emphasized that recurrence intervals, regardless of length, always refer to an average period of time (or years) in which flows at a given station will be equal to or less than the associated low-flow value once. A 10-year recurrence interval does not imply that the low-flow value will have a non-exceedance every 10 years; it does indicate, however, that the average time between recurrences is equal to 10 years. Consequently, an observed interval between a non-exceedance of the 7Q10 may be as short as 1 year or may be considerably longer than 10 years.

The low-flow frequency curve is generated by application of equation 1 to a set of annual minimum $N$-day average flows for a range of specified return periods. To estimate low-flow statistics for recurrence intervals greater than the period of record, these frequency curves must be extended. For this study, the following criteria were used to limit the extension of the curves based on the period of record at the station, and the following criteria were established for extending frequency curves:

1. Curves for stations with 10 or more years of annual lowflow streamflow record but less than 20 years of record were extended to a recurrence interval of 20 years;

2. Curves for stations with 20 or more years of record but less than 30 years of record were extended to a recurrence interval of 30 years; and

3. Curves for stations with 30 or more years of record were extended to a recurrence interval of 50 years. No data were compiled for recurrence intervals greater than 50 years.

An example of the frequency curve using the log-Pearson Type III curve-fitting procedure is illustrated in figure 6 .

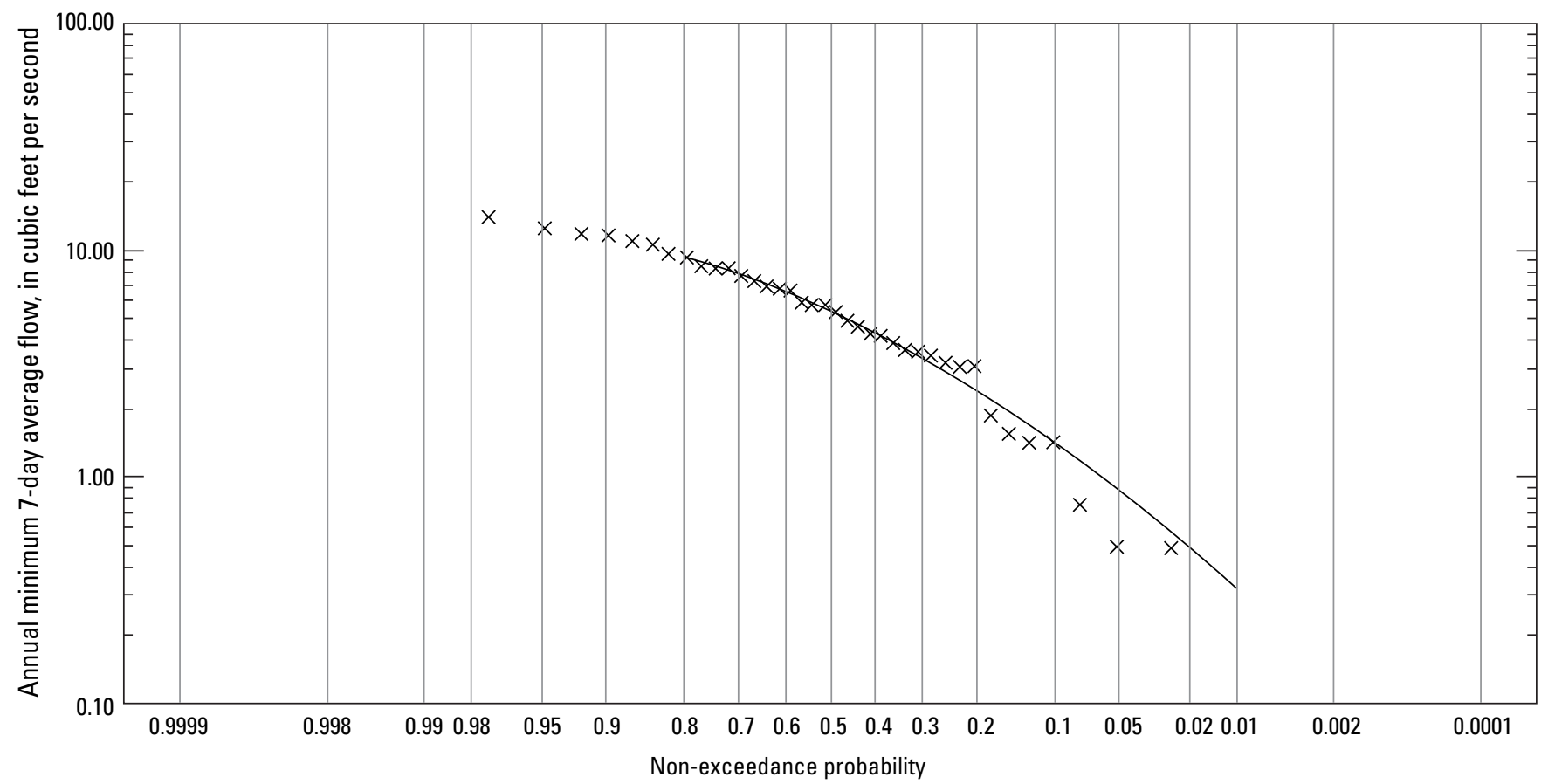

Figure 6. Low-flow frequency curve for the annual minimum 7-day average streamflow for the U.S. Geological Survey streamgaging station 02146750, McAlpine Creek below McMullen Creek near Pineville, NC. 


\section{Record-Extension Technique}

Streamflow statistics often are needed to estimate probabilities of occurrences for periods much longer than the actual measured period of record. Consequently, short records that may have been collected during an unusually dry, wet, or otherwise unrepresentative period may not represent the more desirable fuller range of potential hydrologic regimes. Under certain conditions, it is possible to extend or augment a short record by using a correlated station having a longer record. The extended record at the short-term record station will better reflect low-flow conditions over a longer period and provide better estimates of low-flow statistics at that station. The record extension can be accomplished in the following manner.

If a linear relation between the logarithms of the $N$-day flows at a short-term record station is determined to be significantly correlated to a concurrent set of the $N$-day flows at a long-term record station, or index station, a mathematical record-extension method known as the Maintenance of Variance Extension, Type 1 (MOVE.1) method (Hirsch, 1982) can be used to extend the record at the short-term record station. The MOVE. 1 relation maintains the mean and the variance of the data at the short-term record station and, therefore, allows for the generation of a longer-term set of data that will possess the statistical characteristics of the actual measured data from the short-term record.

The MOVE. 1 equation is

$$
Y_{i}=\bar{Y}+\frac{S_{y}}{S_{x}}\left(X_{i}-\bar{X}\right)
$$

where

$$
\begin{aligned}
& Y_{i} \quad \text { is the logarithm of the estimated } N \text {-day } \\
& \text { flow for the short-term record station; } \\
& \bar{Y} \quad \text { is the mean of the logarithms of } N \text {-day } \\
& \text { flows for the concurrent period at the short- } \\
& \text { term record station; } \\
& S_{y} \quad \text { is the standard deviation of the logarithms } \\
& \text { of } \mathrm{N} \text {-day flows for the concurrent period at } \\
& \text { the short-term record station; } \\
& S_{x} \quad \text { is the standard deviation of the logarithms } \\
& \text { of } \mathrm{N} \text {-day flows for the concurrent period } \\
& \text { at the long-term record station or index } \\
& \text { station; } \\
& X_{i} \quad \text { is the logarithm of the flow statistic or } \\
& \text { observed } N \text {-day flow at the index station; } \\
& \text { and } \\
& \bar{X} \quad \text { is the mean of the logarithms of the } N \text {-day } \\
& \text { flows for the concurrent period at the index } \\
& \text { station. }
\end{aligned}
$$

In order for an index station to be considered for this study, it had to have (1) a minimum of 10 years of concurrent record relative to the short-term record station, (2) similar basin geology as the short-term record station, and (3) a basin less than 10 times larger than the size of the smaller basin (Telis, 1991). A minimum correlation coefficient between concurrent flows has not been developed for the MOVE.1 technique; however, similar correlation studies have used values ranging from 0.70 to 0.80 (Hydrology Subcommittee of the Interagency Advisory Committee on Water Data, 1982; Stedinger and Thomas, 1985; Ries, 1994; Nielsen, 1999). In addition, if the record at the short-term record station or available index station included zero flows, record extensions were not applied because including such values in record-extension techniques has not be adequately tested (Julie Kiang, U.S. Geological Survey Office of Surface Water, written commun., January 26, 2010).

For gaging stations that have relatively long records, such as 30 years or more, record extension may still be beneficial if an index station is available that has additional record collected under hydrologic conditions that are not included in the record being analyzed. Currently, there are no standard criteria for assessing when use of MOVE. 1 is warranted with respect to improvement in the low-flow statistics at such stations. Therefore, for this investigation, an arbitrary criterion was set. The 7-day low-flow statistics at the index station were computed using the complete period of record and the period of record that was concurrent with the station of interest. If the average difference in the 7-day low-flow statistics for the two periods at the index station was greater than 10 percent, MOVE. 1 was used to augment the record at the station of interest. Otherwise, no augmentation was done. On the basis of this criterion, no station records were augmented for the Catawba-Wateree and Santee River Basins.

At station 02148300 , three additional years of record were collected since the previous investigation by Zalants (1991b). An assessment was made to determine if the station was suitable for record augmentation. The findings indicated that the station was not suitable for a record extension due to substantial influence at the lower flow range from upstream discharges. Two National Pollutant Discharge Elimination System (NPDES) permitted facilities discharge upstream from station 02148300 and are considered to have minor environmental impacts and, therefore, do not require discharge reporting (Wade Cantrell, South Carolina Department of Health and Environmental Control, written commun., 2014). A graphical comparison of duration curves for a concurrent period of record (July 26, 1968, to September 30, 1980) at station 02148300 was made with two potential index stations that are located in the same physiographic province: 02135300, Scape Ore Swamp near Bishopville, SC, and 02169570, Gills Creek at Columbia, SC (fig. 7). The comparison showed that for the higher daily mean flows, the duration curves tend to be parallel indicating similar flow patterns. However, for the lower daily mean flows, the slope of the duration curve for station 02148300 was flatter than those of the other two stations (fig. 7A). When plotted on the basis of streamflow per square mile, the distinction is even more pronounced with the duration curve for station 02148300 crossing the duration curves for stations 02135300 and 02169570 (fig. $7 B$ ) indicating higher runoff per square mile for the lower flows, which is assumed to be from the upstream NPDES discharges. Consequently, it was determined that station 02148300 was not suitable for record augmentation. 

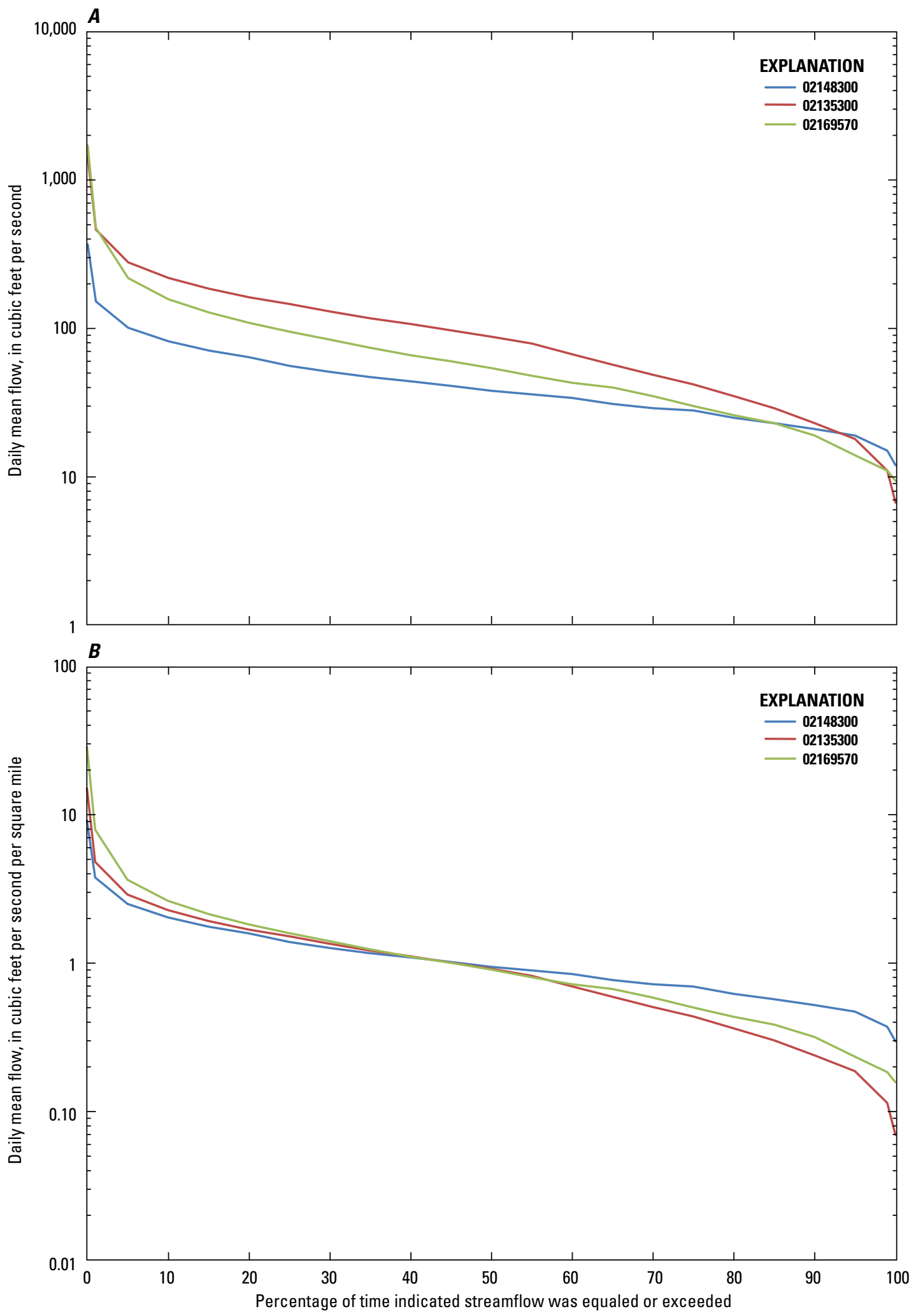

Figure 7. Flow-duration curves for U.S. Geological Survey South Carolina streamgaging stations 02148300 , Colonels Creek near Leesburg, SC, 02135300, Scape Ore Swamp near Bishopville, SC, and 02169570, Gills Creek at Columbia, SC, for the concurrent period from July 26, 1968, to September 30, 1980, in $(A)$ cubic feet per second and $(B)$ cubic feet per second per square mile. 


\section{Partial-Record Type Analysis}

As previously discussed, when limited streamflow data are collected on a systematic basis over a period of years for use in hydrologic analyses, the data-collection site is called a partial-record (PR) station (Zalants, 1991a). With respect to low-flow statistics, once a sufficient number of base-flow measurements have been made over a reasonable period of time, techniques can be used to transfer low-flow statistics from an index station to the PR station (Riggs, 1972). If the relation between the flows at the PR station and the index station is linear, mathematical correlation methods, such as MOVE.1, can be used (Hirsch, 1982). If the relation is nonlinear, then a graphical correlation described by Riggs (1972) can be used.

The MOVE. 1 technique can be used to establish a relation between the concurrent daily mean flows. In order to use daily mean flows that are representative of low-flow conditions, only concurrent flows that are less than or equal to the 90-percent flow duration at the index station were used in the MOVE. 1 analysis. That relation is then used to transfer a limited set of low-flow statistics from an appropriate index station to the PR station. Similar criteria as were described for extending the record at a short-term record station can be used with the exception of the concurrent-record length. U.S. Geological Survey Office of Surface Water Technical Memorandum No. 86.02 (U.S. Geological Survey, 1985) recommended that only the 7Q2 and 7Q10 statistics be estimated for the PR stations. Because of the limited records available at the PR stations, providing a broader set of statistics would imply an accuracy that is not warranted.

The same MOVE. 1 equation (eq. 2) as described previously is used to transfer the low-flow characteristic from the index station to the PR station. The difference is that now $X_{i}$ is the low-flow characteristic computed from the index or long-term record station, and $Y_{i}$ is the low-flow characteristic estimated at the PR station. Seven CR stations in the CatawbaWateree or Santee River Basins had at least 5 years but less than 10 years of record (table 4). For three of those stations, 021459367, Big Dutchman Creek at Rock Hill, SC; 02146110, Manchester Creek at Rock Hill, SC; and 021473428, Wildcat Creek below Rock Hill, SC, no suitable index station was found. Two additional CR stations, 021473426, Tools Fork Creek near Rock Hill, SC, and 02172035, Turkey Creek above Huger, SC, that had at least 5 years but less than 10 years of record experienced zero flows and, therefore, were not considered suitable for record extensions. Two additional CR stations, 0214676115, McAlpine Creek at Secondary Road 2964 near Camp Cox, SC, and 02146800, Sugar Creek near Fort Mill, SC, had at least 5 years but less than 10 years of record for which the streamflows are substantially influenced by wastewater treatment plant discharges and, consequently, were not considered suitable for record extensions.

\section{Flow-Duration Analysis}

Flow durations represent the percentage of time that a specified streamflow is equaled or exceeded during a given period (Searcy, 1959). Flow durations are computed by sorting the daily mean flows for the period of record from the largest value to the smallest value and assigning each streamflow value a rank, starting from 1 to the largest value. The frequencies of exceedance are then computed using the Weibull formula for computing plotting position (Helsel and Hirsch, 1992):

$$
P=100 *[M /(n+1)],
$$

where

$$
\begin{array}{cl}
P & \begin{array}{l}
\text { is the probability that a given flow will be } \\
\text { equaled or exceeded (percentage of time), }
\end{array} \\
M & \begin{array}{l}
\text { is the ranked position (dimensionless), and } \\
\text { is the number of events for the period of } \\
\text { record (dimensionless). }
\end{array}
\end{array}
$$

Flow durations are a summary of the past hydrologic events. Yet, if the streamflow during the period for which the duration curve is based is a sufficiently long period of record, the statistics can be used as an indicator of probable future conditions (Searcy, 1959). In order to compare flow durations at different stations or in different basins, flow-duration estimates can be normalized by drainage area to represent a streamflow per unit area. Again, it should be noted that the most useful comparisons will be those based on similar lengths of record from similar hydrologic periods.

Flow durations for this report are presented in tabular form for the 5-, 10-, 25-, 50-, 75-, 90-, and 95-percent exceedances (table 2). To be consistent with the low-flow statistics, flow durations were computed based on the climatic year using daily mean flows through March 2012.

\section{Analytical Considerations}

Streamflow statistics computed at CR stations are based on historical streamflow records but can be useful for making decisions about the future if it can be reasonably assumed that the future streamflow patterns are likely to be relatively similar to historical streamflow patterns. Thus, streamflow statistics computed from records that capture a wide range of hydrologic conditions are more desirable. When a stream is influenced by regulation, techniques for estimating low-flow statistics that are similar to those used for analysis of natural streams can be applied; however, consistency in the regulation patterns also must be considered. If assessments of the historical streamflow records indicate that the regulation patterns have been relatively consistent and if the logarithm of the annual minimum flows for a given averaging period are consistent with a Pearson Type III distribution, low-flow statistics can be computed for the regulated station with the understanding that using those statistics for future planning assumes relatively similar regulation patterns will occur in the future (Riggs, 1972). Special considerations for 
the low-flow analyses included in this report are discussed in the following sections.

\section{Stations on the Main Stem of the Catawba and Wateree Rivers}

Station 02146000, Catawba River near Rock Hill, SC, has daily mean flow data from October 1895 to September 1902, which reflect unregulated conditions, and April 1942 to the current year (2013), which reflect regulated conditions. The reservoirs upstream from station 02146000 were built at various dates between 1915 and 1963 (U.S. Army Corps of Engineers, 2012). In 2003, Duke Energy began the relicensing process for its hydroelectric projects located in the Catawba and Wateree River Basins (Duke Energy, 2006). Part of the comprehensive relicensing agreement dated December 22, 2006, provides for minimum flow releases from the hydroelectric plants. Consequently, the low-flow statistics that could be generated from historical streamflow records collected prior to this agreement may not be reflective of future conditions. As a result, low-flow frequency statistics were not generated for the following stations: 02146000 , Catawba River near Rock Hill, SC; 02147000, Catawba River near Catawba, SC; 02147020, Catawba River below Catawba, SC; 02148000, Wateree River near Camden, SC; and 02148315, Wateree River below Eastover, SC. However, the duration of daily flow and exceedance percentiles of annual minimum 7-day average flows were generated to provide a historical perspective of streamflows at the stations (table 2). The drainage areas for stations 02147000 and 02147020 differ by less than 1 percent; consequently, for the flow duration analysis, the data from those two stations were combined. For station 02148315, Wateree River below Eastover, SC, the daily mean flows only represent those that are confined to the main channel. As a result, streamflows greater than 10,000 cubic feet per second $\left(\mathrm{ft}^{3} / \mathrm{s}\right)$ are not reported (U.S. Geological Survey, 2011).

\section{Stations 02146750, McAlpine Creek below McMullen Creek near Pineville, NC, and 0214678175, Steele Creek at Secondary Road 1441 near Pineville, NC}

Stations 02146750 and 0214678175 are located in North Carolina and, thus, are not under the jurisdiction of the SCDHEC water-quality monitoring program. However, because a number of USGS stations that are located in the Catawba River Basin in and around Rock Hill, SC, do not currently have sufficient lengths of record to compute low-flow frequency statistics, low-flow frequency statistics were computed for stations 02146750 and 0214678175 (tables 2 and 4). For nearby ungaged basins with similar basin characteristics, the statistics from stations 02146470 and 0214678175 may be useful for providing low-flow estimates at the ungaged sites, using techniques such as the drainage-area ratio method (U.S. Geological Survey, 2013a).

\section{Stations 02171500, Santee River near Pineville, SC, 02171700, Santee River near Jamestown, SC, and 02172002, Lake Moultrie Tailrace Canal at Moncks Corner, SC}

The hydrology of the Santee River Basin has undergone substantial changes since the construction of Lake Marion and Lake Moultrie around 1941 and the implementation of the rediversion canal beginning around 1985 (Patterson and others, 1996; South Carolina Department of Natural Resources, 2009). Because of these extensive hydrologic modifications, low-flow frequency statistics were not computed for stations 02171500 , 02171700 , and 02172002 . However, the duration of daily flow and exceedance percentiles of annual minimum 7-day average flows were generated to provide a historical perspective of streamflows at the three stations (table 2).

\section{Considerations for Accuracy of Low-Flow Statistics}

With respect to streamflow statistics, the period of collected record can be thought of as a sample, or small portion of the population, which represents all possible measurements. Statistics allow for making inferences about the characteristics of the population based on samples from the population. For example, statistical measures, such as mean, standard deviation, or skew coefficient, can be described in terms of the sample and then used to make inferences about the population from which the sample was obtained. Statistical measures computed from the sample record are estimates of what the measure would be if the entire population were known and used to compute the given measure. Consequently, the accuracy of low-flow statistics at streamgaging stations is related to the lengths of records (samples from the population) upon which the statistics are based. The longer the period of record at a streamgaging station that covers a broad range of hydrologic conditions, the more accurate or reflective of long-term conditions the low-flow statistics will be.

The streamflow statistics for short-term records are much more sensitive to extreme hydrologic events than those for longterm records. As a result, streamflow statistics, whether high or low, from one 10-year period may differ significantly from another 10-year period (Dalrymple, 1960). Thus, a long-term record is always more desirable when computing streamflow statistics. Comparisons showing the effects of record length and hydrologic conditions on low-flow statistics using several long-term stations with record lengths of 77,70 , and 70 years were provided in Feaster and Guimaraes (2009), Guimaraes and Feaster (2010), and Feaster and Guimaraes (2012), respectively. A suitable unregulated station with a similar length of record was not available for a comparable analysis for the Catawba-Wateree and Santee River Basins. 


\section{Comparison with Previously Published Low-Flow Statistics}

Low-flow frequency statistics are influenced by length of record, hydrologic regime under which the data were collected, analytical techniques used, and other factors, such as urbanization, diversions, and droughts that may have occurred in the basin. The last systematic update of low-flow statistics in South Carolina included data through March 1987 (the 1986 climatic year). Since that time, several substantial droughts have occurred, including one of the most severe droughts in recent history that occurred between 1998 and 2002 and a more recent drought from 2006 to 2009 (South Carolina Department of Natural Resources, 2004, 2013). Less severe droughts were reported in 1988, 1990, 1993, and 1995 (Mizzell, 2008).

Of the 12 stations included in this study, only 3 had 7Q10 values computed in previous publications (Bloxham (1979) or Zalants (1991b)). The most recent previously published 7Q10 values for these two stations were compared with the current values, and percent differences were computed as follows:

Percent difference $=[($ current 7Q10 - previous 7Q10)

$/$ previous 7Q10] x 100
As computed, the percent difference indicates the percentage of change from the previously published 7Q10 value. For station 02148300, Colonels Creek near Leesburg, SC, the 7Q10 decreased -28.5 percent (from $13 \mathrm{ft}^{3} / \mathrm{s}$ to $9.3 \mathrm{ft}^{3} / \mathrm{s}$ ) from the value published by Zalants (1991b). It should be noted, however, that the additional data for that station were collected from April 2004 through March 2007 (table 5). For station 02147500, Rocky Creek at Great Falls, SC, the 7Q10 decreased -71.0 percent (from $1.0 \mathrm{ft}^{3} / \mathrm{s}$ to $0.29 \mathrm{ft}^{3} / \mathrm{s}$ ) from the value published by Zalants (1991b). The additional data at station 02147500 were from April 1987 to March 2012 and, thus, included the severe droughts of the last decade or so. Of the 10 smallest annual minimum 7-day average flows from the 56 years of record analyzed, 7 occurred between climatic years 2000 and 2011 with the other three lowest annual minimum 7-day average flows occurring in 1954, 1956, and 1957. For station 02171680, Wedboo Creek near Jamestown, SC, additional data were collected from April 1987 through September 1992; however, the additional years of record did not change the 7Q10 value of zero.

Table 5. Differences between the annual minimum 7-day average streamflow with a 10-year recurrence interval in this report and previously published values for continuous-record streamgaging stations in the Catawba-Wateree and Santee River Basins of South Carolina.

[USGS, U.S. Geological Survey; $\mathrm{ft}^{3} / \mathrm{s}$, cubic feet per second; CY, climatic year]

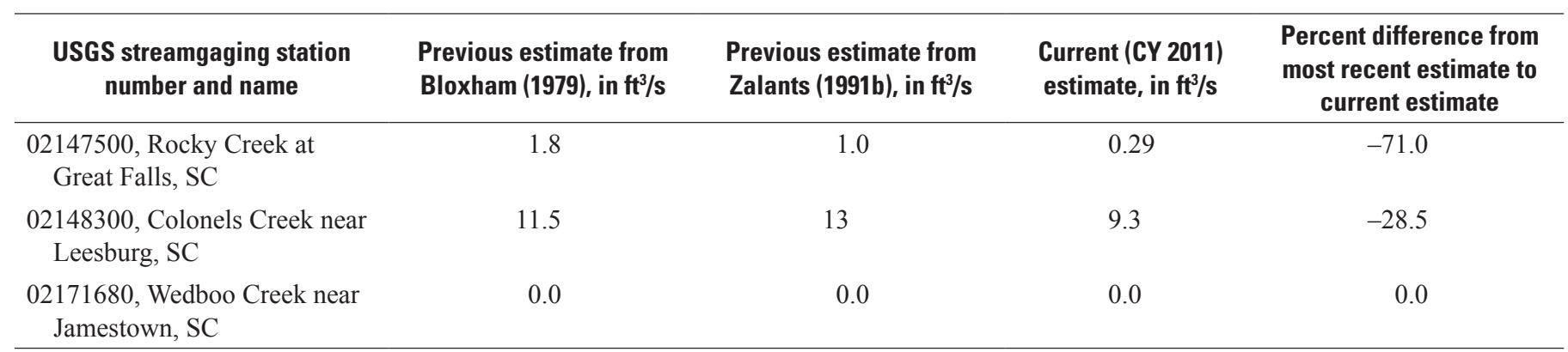




\section{Summary}

This report, prepared in cooperation with the South Carolina Department of Health and Environmental Control, provides updated low-flow statistics at continuous-record streamgaging stations operated by the U.S. Geological Survey in the Catawba-Wateree and Santee River Basins of South Carolina. The continuous-record streamgaging stations included in this study were analyzed based on four categories of stations: (1) long-term record stations; (2) short-term record stations that have at least 10 years of record; (3) stations that have between 5 and 10 years of record and that were analyzed for a limited set of low-flow statistics, using techniques typically used in analyzing partial-record stations; and (4) regulated stations. For this investigation, record extension techniques were not used due to conditions not being met that warranted applying such techniques. Based on the length of record available at the continuous-record streamgaging stations, low-flow frequency statistics were estimated for consecutive 1-, 3-, 7-, 14-, 30-, 60-, and 90-day average minimum flows with recurrence intervals of $2,5,10,20,30$, and 50 years. Additionally, daily flow durations for the 5-, 10-, 25-, 50-, 75-, 90-, and 95-percent probabilities of exceedance were computed for the stations. For the Catawba-Wateree and Santee River Basins, none of the regulated stations were considered appropriate for computing low-flow $\mathrm{N}$-day frequency statistics; consequently, only exceedance percentiles of annual minimum 7-day flows and daily flow durations were computed.

Of the 13 streamgaging stations included in this study, 3 stations had 7Q10 low-flow statistics that were previously published in U.S. Geological Survey reports: 02147500, Rocky Creek at Great Falls, SC, 02148300, Colonels Creek near Leesburg, SC, and 02171680 , Wedboo Creek near Jamestown, SC. Comparison of the 7Q10 values for these three stations as published by Zalantas (1991b) showed that for station 02147500, the $7 \mathrm{Q} 10$ decreased from $1.0 \mathrm{ft}^{3} / \mathrm{s}$ to $0.29 \mathrm{ft}^{3} / \mathrm{s}$, a percent difference of -71.0 percent; for station 02148300 , the $7 \mathrm{Q} 10$ value decreased from $13 \mathrm{ft}^{3} / \mathrm{s}$ to $9.3 \mathrm{ft}^{3} / \mathrm{s}$, a percent difference of -28.5 percent; and for station 02171680 , the $7 \mathrm{Q} 10$ remained unchanged at $0.0 \mathrm{ft}^{3} / \mathrm{s}$.

\section{References Cited}

Barker, A.C., 1986, Base-flow measurements at partial-record sites on small streams in South Carolina: U.S. Geological Survey Open-File Report 86-143, 97 p.

Bloxham, W.M., 1976, Low-flow characteristics of streams in the Inner Coastal Plain of South Carolina: South Carolina Water Resources Commission Report No. 5, 41 p.
Bloxham, W.M., 1979, Low-flow frequency and flow duration of South Carolina streams: South Carolina Water Resources Commission Report No. 11, 90 p.

Bloxham, W.M., 1981, Low-flow characteristics of ungaged streams in the Piedmont and Lower Coastal Plain of South Carolina: South Carolina Water Resources Commission Report No. 14, 48 p.

Bloxham, W.M., Siple, G.E., and Cummings, T.R., 1970, Water resources of Spartanburg County, South Carolina: South Carolina Water Resources Commission Report No. 3, $112 \mathrm{p}$.

Cooke, C.W., 1936, Geology of the Coastal Plain of South Carolina: U.S. Geological Survey Bulletin 867, 196 p.

Dalrymple, Tate, 1960, Flood-frequency analyses, manual of hydrology_Part 3. Flood-flow techniques: U.S. Geological Survey Water-Supply Paper 1543-A, 80 p.

Duke Energy, 2006, Comprehensive relicensing agreement for the Catawba-Wateree Hydro Project: FERC Project No. 2232, accessed October 22, 2013, at $h t t p: / / w w w . d u k e-e n e r g y . c o m / p d f$ s/relicensing/ comp_relicensing_agreement.pdf.

Eidson, J.P., Lacy, C.M., Nance Luke, Hansen, W.F., Lowery, M.A., and Hurley, N.M., Jr., 2005, Development of a 10- and 12-digit hydrologic unit code numbering system for South Carolina, 2008: U.S. Department of Agriculture, Natural Resources Conservation Service, 38 p., 1 pl.

Feaster, T.D., and Conrads, P.A., 2000, Characterization of water quality and simulation of temperature, nutrients, biochemical oxygen demand, and dissolved oxygen in the Wateree River, South Carolina, 1996-98: U.S. Geological Survey Water-Resources Investigations Report 99-4234, $90 \mathrm{p}$.

Feaster, T.D., Conrads, P.A., Guimaraes, W.B., Sanders, C.L., Jr., and Bales, J.D., 2003, Simulation of temperature, nutrients, biochemical oxygen demand, and dissolved oxygen in the Catawba River, South Carolina, 1996-97: U.S. Geological Survey Water-Resources Investigations Report 03-4092, 123 p.

Feaster, T.D., and Guimaraes, W.B., 2009, Low-flow frequency and flow duration of selected South Carolina streams in the Pee Dee River Basin through March 2007: U.S. Geological Survey Open-File Report 2009-1171, 39 p.

Feaster, T.D., and Guimaraes, W.B., 2012, Low-flow frequency and flow duration of selected South Carolina streams in the Saluda, Congaree, and Edisto River Basins through March 2009: U.S. Geological Survey Open-File Report 2012-1253, 53 p. 
Guimaraes, W.B., and Feaster, T.D., 2010, Low-flow frequency and flow duration of selected South Carolina streams in the Broad River Basin through March 2008: U.S. Geological Survey Open-File Report 2010-1305, 47 p.

Helsel, D.R., and Hirsch, R.M., 1992, Studies in environmental science 49 - Statistical methods in water resources: Amsterdam, Elsevier Science, 529 p.

Hirsch, R.M., 1982, A comparison of four record extension techniques: Water Resources Research, v. 18, no. 4, p. 1081-1088.

Hydrology Subcommittee of the Interagency Advisory Committee on Water Data, 1982, Guidelines for determining flood frequency: U.S. Geological Survey Bulletin 17B, $183 \mathrm{p}$.

Johnson, F.A., Siple, G.E., and Cummings, T.R., 1968, A reconnaissance of the water resources of Pickens County, South Carolina: South Carolina Water Resources Commission Report No. 1, 69 p.

Langbein, W.B., and Iseri, K.T., 1983, General introduction and hydrologic definitions, manual of hydrology-Part 1. General surface-water techniques (3d ed.): U.S. Geological Survey Water-Supply Paper 1541-A, 29 p.

Lins, H.F., Hirsch, R.M., and Kiang, Julie, 2010, WaterThe Nations fundamental climate issue, A white paper on the U.S. Geological Survey role and capabilities: U.S. Geological Survey Circular 1347, 9 p. (Also available at $h t t p: / / p u b s . u s g s . g o v / c i r c / 1347 /$.)

Mizzell, Hope, 2008, Improving drought detection in the Carolinas-Evaluation of local, State, and Federal drought indicators: Columbia, South Carolina, Department of Geology, University of South Carolina, Ph.D. dissertation, $149 \mathrm{p}$.

Nielsen, J.P., 1999, Record extension and streamflow statistics for the Pleasant River, Maine: U.S. Geological Survey Water-Resources Investigations Report 99-4078, 22 p.

North Carolina State University, 2013, Catawba

River Basin, accessed October 18, 2013, at

http://www.water.ncsu.edu/catawba.html.

Patterson, G.G., Cooney, T.W., and Harvey, R.M., 1996, Sediment transport and deposition in Lakes Marion and Moultrie, South Carolina, 1942-85: U.S. Geological Survey Water-Resources Investigations Report 95-4236, 73 p.

Ries, K.G., III, 1994, Estimation of low-flow duration discharges in Massachusetts: U.S Geological Survey Water-Supply Paper 2418, 50 p.

Riggs, H.C., 1972, Low-flow investigations: U.S. Geological Survey Techniques of Water Resources Investigations, book 4, chap. B1, $18 \mathrm{p}$.
Riggs, H.C., 1985, Streamflow characteristics: New York, Elsevier, $249 \mathrm{p}$.

SAS Institute, Inc., 1989, SAS user's guide-Statistics: Cary, N.C., SAS Institute, Inc., 583 p.

Schaffranek, R.W., Baltzer, R.A., and Goldberg, D.C., 1981, A model for simulation of flow in singular and interconnected channels: U.S. Geological Survey Techniques of Water-Resources Investigations, book 7, chap. C3, 110 p.

Searcy, J.K., 1959, Flow-duration curves, manual of hydrology - part 2. Low-flow techniques: U.S. Geological Survey Water-Supply Paper 1542-A, p.1-33.

South Carolina Department of Health and Environmental Control, 2005, Watershed water quality assessmentSantee River Basin: Columbia, S.C., Bureau of Water, Technical Report No. 013-05.

South Carolina Department of Health and Environmental Control, 2009, Watersheds and TMDLs, accessed February 19, 2009, at http://www.scdhec.gov/environmental/ admin/htm/eqcpubs.htm.

South Carolina Department of Health and Environmental Control, 2012, Watershed water quality assessmentCatawba River Basin: Columbia, S.C., Bureau of Water, Technical Report No. 1109-12.

South Carolina Department of Health and Environmental Control, 2013, Watersheds-Santee River Basin, accessed October 24, 2013, at http://www.scdhec.gov/environment/ water/shed/san_ashl.htm.

South Carolina Department of Natural Resources, 2004, Hydrologic effects of the June 1998-August 2002 drought in South Carolina: Columbia, S.C., Land, Water \& Conservation Division Water Resources Report 34, 49 p.

South Carolina Department of Natural Resources, 2009, South Carolina state water assessment ( $2 \mathrm{~d}$ ed.): Columbia, S.C., Land, Water \& Conservation Division.

South Carolina Department of Natural Resources, 2013, South Carolina current drought status, accessed October 21, 2013, at http://www.dnr.sc.gov/climate/sco/ Drought/drought_press_release.php.

Stallings, J.S., 1967, South Carolina streamflow characteristics-Low-flow frequency and flow duration: U.S. Geological Survey Open-File Report, 83 p.

Stedinger, J.R., and Thomas, W.O., Jr., 1985, Low-flow frequency estimation using base-flow measurements: U.S. Geological Survey Open-File Report 85-95, 22 p.

Telis, P.A., 1991, Low-flow and flow-duration characteristics of Mississippi streams: U.S. Geological Survey WaterResources Investigations Report 90-4087, 214 p. 
U.S. Army Corps of Engineers, 2012, National inventory of dams, accessed August 6, 2012, at https://nid.usace.army.mil.

U.S. Environmental Protection Agency, 2009, Polluted runoff (nonpoint source pollution), appendix — case studies, accessed June 27, 2009, at http://www.epa.gov/owow/nps/urbanize/appendix.html.

U.S. Geological Survey, 1979, Programs and Plans-Low-flow programs: U.S. Geological Survey Office of Surface Water Technical Memorandum No. 79.06, accessed April 26, 2007, at http://water.usgs.gov/admin/memo/SW/sw79.06.html.

U.S. Geological Survey, 1985, Programs and Plans-Lowflow frequency estimation at partial-record sites: U.S. Geological Survey Office of Surface Water Technical Memorandum No. 86.02, accessed May 7, 2007, at http://water.usgs.gov/admin/memo/SW/sw86.02.html.

U.S. Geological Survey, 2011, Water-Data Report 2011: 02148315 Wateree River below Eastover, SC: accessed October 23, 2013, at http://wdr.water.usgs.gov/wy2011/ $p d f s / 02148315.2011 . p d f$.
U.S. Geological Survey, 2013a, Computing low-flow statistics for ungaged locations on Pennsylvania streams by use of drainage-area ratios, accessed October 23, 2013 at http://paapps.er.usgs.gov/flowstats/revised_deplowflow.pdf.

U.S. Geological Survey, 2013b, National Streamflow Information Program (NSIP), accessed October 22, 2013, at http://water.usgs.gov/nsip/history1.html.

Zalants, M.G., 1991a, Low-flow characteristics of natural streams in the Blue Ridge, Piedmont, and upper Coastal Plain Physiographic Provinces of South Carolina: U.S. Geological Survey Water-Resources Investigations Report 90-4188, 92 p.

Zalants, M.G., 1991b, Low-flow frequency and flow duration of selected South Carolina streams through 1987: U.S. Geological Survey Water-Resources Investigations Report 91-4170, $87 \mathrm{p}$. 
Table 2. Low-flow statistics for continuous-record streamgaging stations in the Catawba, Wateree, and Santee River Basins of South Carolina.

[lat, latitude; long, longitude; $\mathrm{ft}$, feet; mi, mile; $\mathrm{mi}^{2}$, square mi; $\mathrm{ft}^{3}$, cubic feet; SCDHEC, South Carolina Department of Health and Environmental Control; USGS, U.S. Geological Survey; $\mathrm{ft}^{3} / \mathrm{s}$, cubic feet per second; water year, the 12-month period from October 1 through September 30 and designated by the year in which the period ends]

Notes: The station low-flow statistics are presented in the following pages in numerical order by station number. See figure 2 for location of the streamgaging stations. 
STATION NAME AND NUMBER.—02146000 Catawba River near Rock Hill, SC

LOCATION.-Lat 3459'05", long 8058'27" referenced to North American Datum of 1927, York County, SC, Hydrologic Unit 03050103, near right bank, at upstream side of foot bridge and just downstream from U.S. Highway 21, 3.5 mi downstream from Lake Wylie Dam, 5.0 mi northeast of Rock Hill, 7.5 mi upstream from Sugar Creek, and at river mile 137.6.

DRAINAGE AREA. $-3,050 \mathrm{mi}^{2}$.

PERIOD OF RECORD.-October 1895 to September 1902, April 1942 to current year.

PERIOD OF ANALYSIS.-April 1942 to March 2012.

REMARKS.-Flow regulated by Lake Wylie (usable capacity, 2,520,500,000 ft³).

ANNUAL MINIMUM 7-DAY AVERAGE FLOW

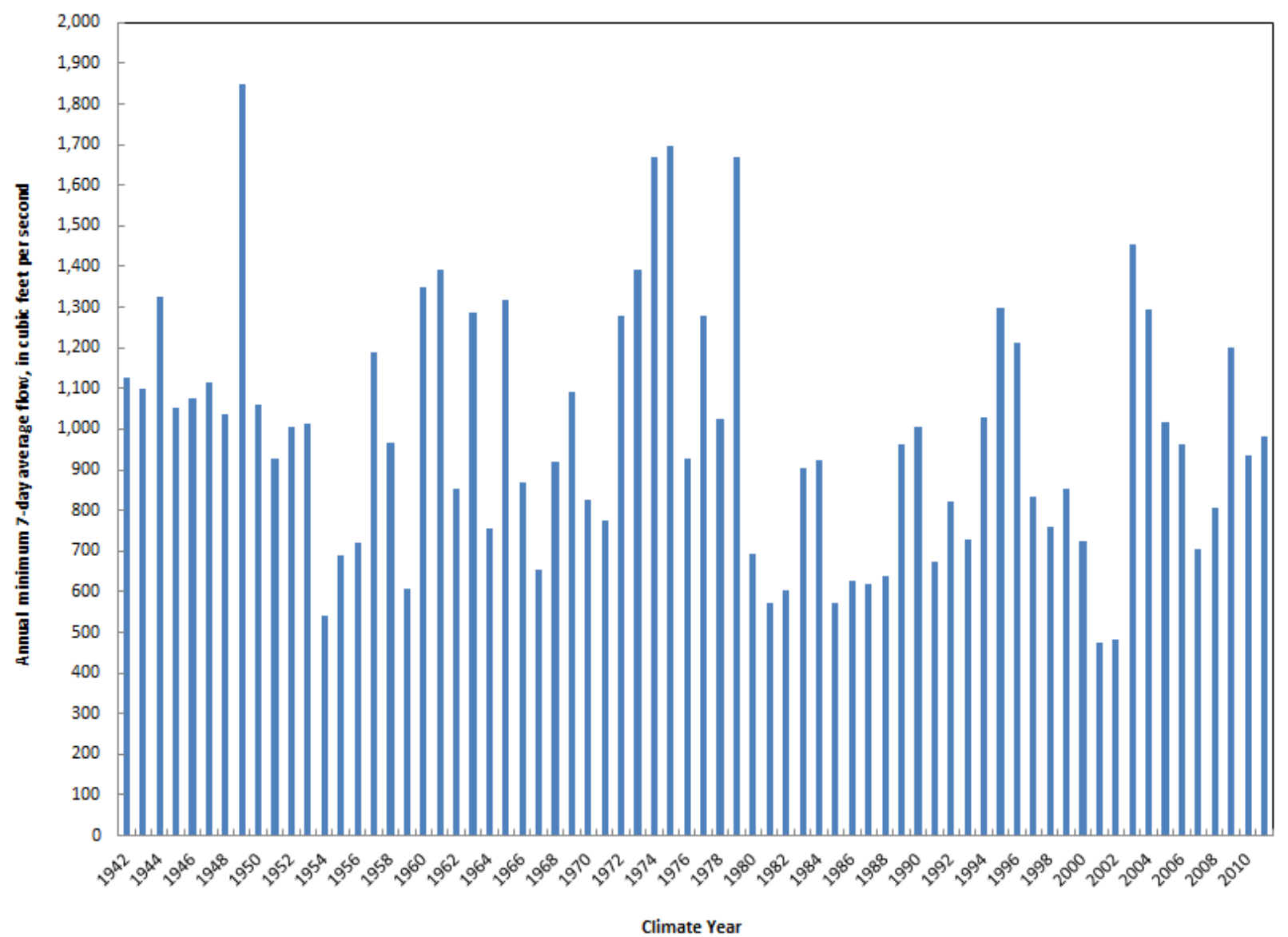

EXCEEDANCE PERCENTILES OF ANNUAL 7-DAY MINIMUM FLOWS

Annual 7-day minimum flow exceeded for indicated percentiles (cubic feet per second)

\begin{tabular}{c|c|c|c|c|c|c|c|c}
\hline \multicolumn{8}{c}{ Annual 7-day minimum flow exceeded for indicated percentiles (cubic feet per second) } \\
\hline 10 & 20 & 30 & 40 & 50 & 60 & 70 & 80 & 90 \\
\hline 1,390 & 1,280 & 1,100 & 1,020 & 963 & 884 & 785 & 696 & 609 \\
\hline
\end{tabular}

DURATION OF DAILY FLOW

Flow equaled or exceeded for indicated percentage of time (cubic feet per second)

\begin{tabular}{c|c|c|c|c|c|c}
\multicolumn{2}{c}{ Flow equaled or exceeded for indicated percentage of time (cubic feet per second) } \\
\hline 5 & 10 & 25 & 50 & 75 & 90 & 95 \\
\hline 10,000 & 8,380 & 5,650 & 3,090 & 1,320 & 860 & 718 \\
\hline
\end{tabular}


STATION NAME AND NUMBER.--02146750 McAlpine Creek below McMullen Creek near Pineville, NC

LOCATION.--Lat 3503'59.39", long 8052'11.46" referenced to North American Datum of 1983, Mecklenburg County, NC, Hydrologic Unit 03050103, on right bank, $150 \mathrm{ft}$ downstream from McMullen Creek, $735 \mathrm{ft}$ upstream from effluent outfall, and

$2.1 \mathrm{mi}$ south of Pineville.

DRAINAGE AREA. $-92.4 \mathrm{mi}^{2}$.

PERIOD OF RECORD.-April 1974 to current year.

PERIOD OF ANALYSIS.-April 1974 to March 2012.

REMARKS.- The SCDHEC requested this station be analyzed along with 0214678175, Steele Creek at Secondary Road 1441 near Pineville, NC, in place of station 0214676115, McAlpine Creek at SR 2964 near Camp Cox, SC, and 02146800, Sugar Creek near Fort Mill, SC, due to those stations having substantial influence from upstream wastewater treatment plant discharges. On the basis of review of withdrawal and discharge data provided by the North Carolina Department of Environment and Natural Resources (NCDENR), there are no significant diversions upstream.

\section{MAGNITUDE AND FREQUENCY OF ANNUAL FLOWS}

\begin{tabular}{|c|c|c|c|c|c|c|c|}
\hline \multirow{2}{*}{$\begin{array}{l}\text { Recurrence } \\
\text { intervals } \\
\text { (years) }\end{array}$} & \multicolumn{7}{|c|}{ Lowest average flow for indicated number of consecutive days } \\
\hline & 1 & 3 & 7 & 14 & 30 & 60 & 90 \\
\hline 2 & 4.0 & 4.4 & 5.3 & 6.5 & 11 & 19 & 27 \\
\hline 5 & 1.6 & 1.9 & 2.4 & 3.3 & 5.3 & 11 & 16 \\
\hline 10 & 0.93 & 1.1 & 1.4 & 2.1 & 3.5 & 7.9 & 12 \\
\hline 20 & 0.55 & 0.66 & 0.88 & 1.5 & 2.4 & 6.2 & 9.6 \\
\hline 30 & 0.41 & 0.50 & 0.68 & 1.2 & 2.0 & 5.4 & 8.4 \\
\hline 50 & 0.28 & 0.35 & 0.49 & 0.91 & 1.5 & 4.6 & 7.3 \\
\hline
\end{tabular}

\section{DURATION OF DAILY FLOW}

Flow equaled or exceeded for indicated percentage of time

(cubic feet per second)

\begin{tabular}{ccccccc}
\hline 5 & 10 & 25 & 50 & 75 & 90 & 95 \\
\hline 613 & 241 & 67 & 30 & 15 & 7.9 & 5.1 \\
\hline
\end{tabular}


STATION NAME AND NUMBER.--0214678175 Steele Creek at Secondary Road 1441 near Pineville, NC

LOCATION.--Lat $35^{\circ} 06^{\prime} 18^{\prime \prime}$, long 805'13" referenced to North American Datum of 1983, Mecklenburg County, NC,

Hydrologic Unit 03050103, on right bank, upstream from culvert on Secondary Road 1441 (Carowinds Boulevard), 4.5 mi west of Pineville.

DRAINAGE AREA. $-6.91 \mathrm{mi}^{2}$.

PERIOD OF RECORD.-May 1998 to current year.

PERIOD OF ANALYSIS.-May 1998 to March 2012.

REMARKS.-The SCDHEC requested this station be analyzed along with 02146750, McAlpine Creek below McMullen Creek near Pineville, NC, in place of station 0214676115, McAlpine Creek at SR 2964 near Camp Cox, SC, and 02146800, Sugar Creek near Fort Mill, SC, due to those stations having substantial influence from upstream wastewater treatment plant discharges. Station 0214678175 is an urbanized basin. On the basis of review of withdrawal and discharge data provided by NCDENR, there are no significant diversions upstream.

\section{MAGNITUDE AND FREQUENCY OF ANNUAL FLOWS}

\begin{tabular}{|c|c|c|c|c|c|c|c|}
\hline \multirow{2}{*}{$\begin{array}{l}\text { Recurrence } \\
\text { intervals } \\
\text { (years) }\end{array}$} & \multicolumn{7}{|c|}{ Lowest average flow for indicated number of consecutive days } \\
\hline & 1 & 3 & 7 & 14 & 30 & 60 & 90 \\
\hline 2 & 0.15 & 0.17 & 0.20 & 0.32 & 0.59 & 1.5 & 2.0 \\
\hline 5 & 0.09 & 0.10 & 0.11 & 0.19 & 0.32 & 0.91 & 1.2 \\
\hline 10 & 0.06 & 0.07 & 0.08 & 0.13 & 0.23 & 0.69 & 0.90 \\
\hline 20 & 0.05 & 0.05 & 0.06 & 0.10 & 0.17 & 0.55 & 0.71 \\
\hline
\end{tabular}

\section{DURATION OF DAILY FLOW}

Flow equaled or exceeded for indicated percentage of time

(cubic feet per second)

\begin{tabular}{ccccccc}
\hline 5 & 10 & 25 & 50 & 75 & 90 & 95 \\
\hline 28 & 12 & 3.8 & 1.5 & 0.64 & 0.35 & 0.25 \\
\hline
\end{tabular}


STATION NAME AND NUMBER.—02147020 Catawba River below Catawba, SC

LOCATION.-Lat 3450'10", long 8052'47" referenced to North American Datum of 1927, York County, SC, Hydrologic Unit 03050103, on right bank, $1.5 \mathrm{mi}$ downstream from Twelvemile Creek, $2.2 \mathrm{mi}$ southeast of Catawba, and at river mile 121.3.

DRAINAGE AREA. $-3,540 \mathrm{mi}^{2}$.

PERIOD OF RECORD.- January 1992 to September 1994 and October 1995 to current year.

PERIOD OF ANALYSIS.-October 1967 to September 1994 and October 1995 to March 2012.

REMARKS.-Because of minor differences in drainage areas (less than 1 percent), the record at 02147020 was combined with the record at 02147000, Catawba River near Catawba, SC (October 1967 to January 1992; drainage area $=3,530 \mathrm{mi}^{2}$ ). Flow regulated by Lake Wylie (usable capacity, 2,520,500,000 $\mathrm{ft}^{3}$ ).

ANNUAL MINIMUM 7-DAY AVERAGE FLOW

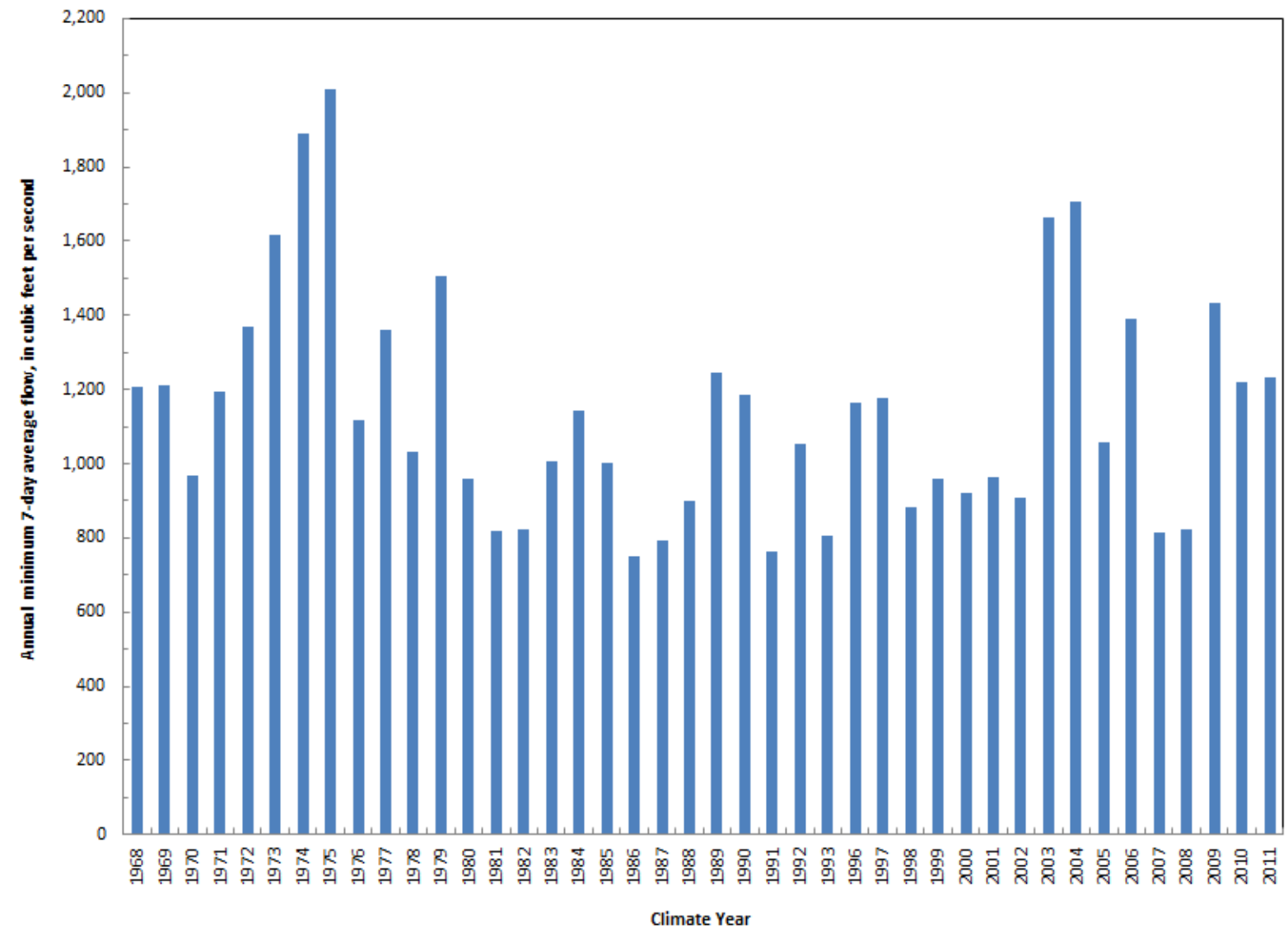

EXCEEDANCE PERCENTILES OF ANNUAL 7-DAY MINIMUM FLOWS

\begin{tabular}{c|c|c|c|c|c|c|c|c}
\hline \multicolumn{8}{c}{ Annual 7-day minimum flow exceeded for indicated percentiles (cubic feet per second) } \\
\hline 10 & 20 & 30 & 40 & 50 & 60 & 70 & 80 & 90 \\
\hline 1,780 & 1,420 & 1,230 & 1,190 & 1,120 & 1,020 & 960 & 885 & 811 \\
\hline
\end{tabular}

DURATION OF DAILY FLOW

Flow equaled or exceeded for indicated percentage of time (cubic feet per second)

\begin{tabular}{c|c|c|c|c|c|c}
\hline \multicolumn{7}{c}{ Flow equaled or exceeded for indicated percentage of time (cubic feet per second) } \\
\hline 5 & 10 & 25 & 50 & 75 & 90 & 95 \\
\hline 11,500 & 9,620 & 6,590 & 3,550 & 1,650 & 1,070 & 933 \\
\hline
\end{tabular}


STATION NAME AND NUMBER.--02147500 Rocky Creek at Great Falls, SC

LOCATION.--Lat 34³3'55", long 8055'12" referenced to North American Datum of 1927, Chester County, SC, Hydrologic Unit 03050103, on left bank, $350 \mathrm{ft}$ downstream from Turkey Branch, $1.0 \mathrm{mi}$ west of Great Falls, and at river mile 1.8.

DRAINAGE AREA.--194 $\mathrm{mi}^{2}$.

PERIOD OF RECORD.--March 1951 to September 1981, and October 1986 to current year.

PERIOD OF ANALYSIS.-April 1951 to March 1981, and April 1987 to March 2012.

REMARKS.- - On the basis of review of withdrawal and discharge data provided by the SCDHEC, there are no significant diversions upstream.

\section{MAGNITUDE AND FREQUENCY OF ANNUAL FLOWS}

\begin{tabular}{|c|c|c|c|c|c|c|c|}
\hline \multirow[t]{2}{*}{$\begin{array}{l}\text { Recurrence } \\
\text { intervals } \\
\text { (years) }\end{array}$} & & & rage fl & icated & cons & & \\
\hline & 1 & 3 & 7 & 14 & 30 & 60 & 90 \\
\hline 2 & 8.1 & 8.2 & 8.9 & 12 & 17 & 22 & 27 \\
\hline 5 & 0.97 & 0.88 & 1.3 & 2.2 & 4.2 & 8.2 & 11 \\
\hline 10 & 0.06 & 0.11 & 0.29 & 0.64 & 1.5 & 4.3 & 6.1 \\
\hline 20 & 0.0 & 0.0 & 0.05 & 0.19 & 0.53 & 2.3 & 3.6 \\
\hline 30 & 0.0 & 0.0 & 0.01 & 0.09 & 0.29 & 1.6 & 2.6 \\
\hline 50 & 0.0 & 0.0 & 0.0 & 0.04 & 0.13 & 1.1 & 1.8 \\
\hline
\end{tabular}

\section{DURATION OF DAILY FLOW}

Flow equaled or exceeded for indicated percentage of time

(cubic feet per second)

\begin{tabular}{ccccccc}
\hline 5 & 10 & 25 & 50 & 75 & 90 & 95 \\
\hline 612 & 315 & 128 & 56 & 26 & 12 & 6.9 \\
\hline
\end{tabular}


STATION NAME AND NUMBER.—02148000 Wateree River near Camden, SC

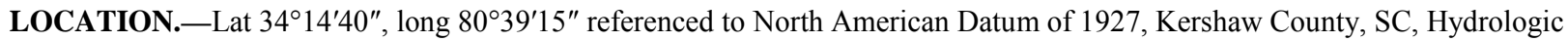
Unit 03050104, on downstream side of pier of downstream bridge on U.S. Highway 1, 1,500 ft downstream from Five and Twenty Creek, 4,000 ft upstream from Seaboard Coast Line Railroad bridge, 2.2 mi west of Camden, 7.4 mi downstream from Wateree Dam, and at river mile 68.8.

DRAINAGE AREA. $-5,070 \mathrm{mi}^{2}$.

PERIOD OF RECORD.—October 1929 to September 1983, and May 1984 to current year.

PERIOD OF ANALYSIS. - October 1929 to September 1983, and May 1984 to March 2012.

REMARKS.-Flow regulated by powerplant at Wateree Reservoir (usable capacity, 2,794,000,000 $\mathrm{ft}^{3}$ ).

ANNUAL MINIMUM 7-DAY AVERAGE FLOW

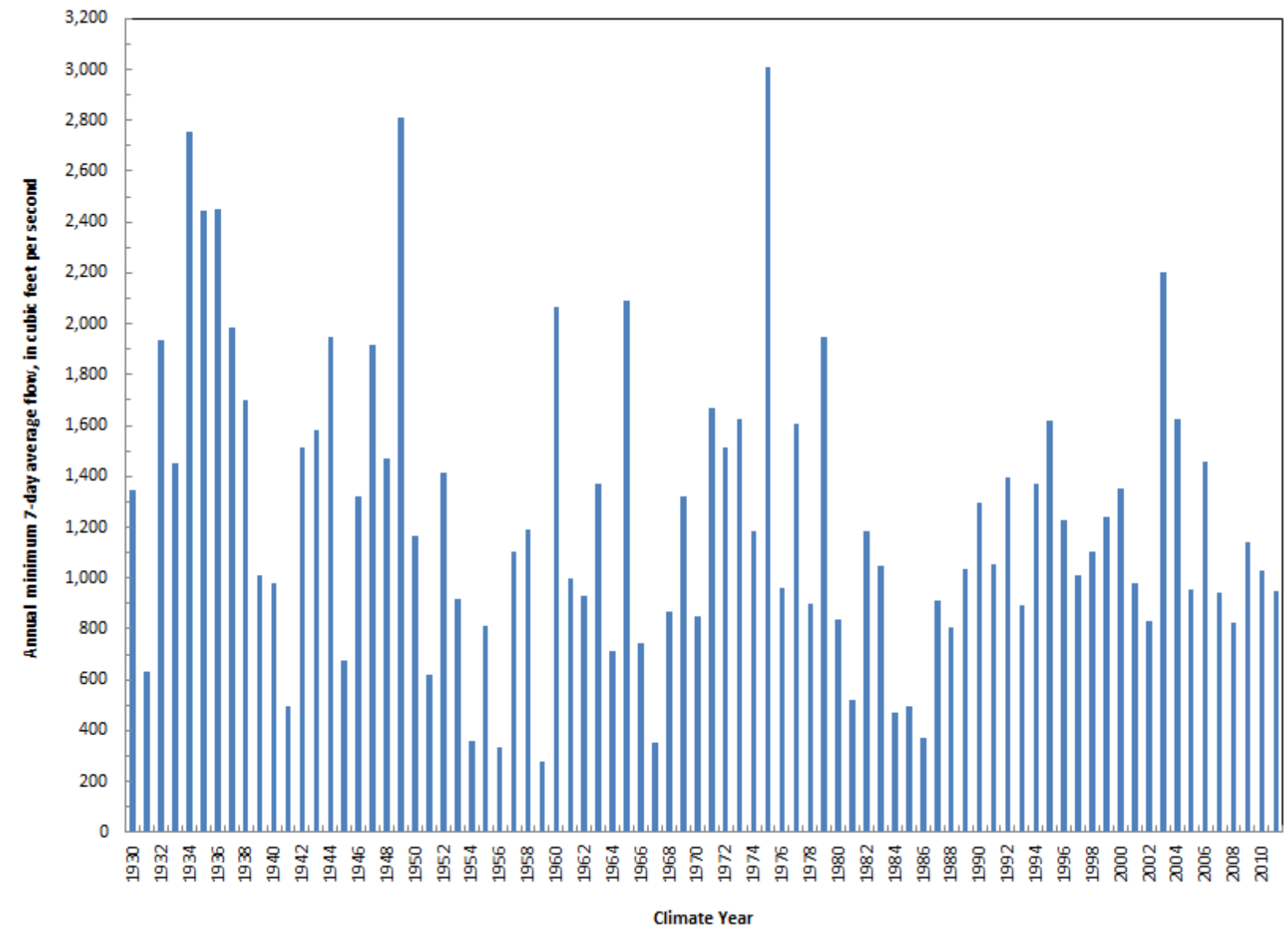

EXCEEDANCE PERCENTILES OF ANNUAL 7-DAY MINIMUM FLOWS

\begin{tabular}{c|c|c|c|c|c|c|c|c}
\hline \multicolumn{8}{c}{ Annual 7-day minimum flow exceeded for indicated percentiles (cubic feet per second) } \\
\hline 10 & 20 & 30 & 40 & 50 & 60 & 70 & 80 & 90 \\
\hline 2,080 & 1,640 & 1,460 & 1,320 & 1,140 & 1,010 & 922 & 824 & 506 \\
\hline
\end{tabular}

DURATION OF DAILY FLOW

Flow equaled or exceeded for indicated percentage of time (cubic feet per second)

\begin{tabular}{c|c|c|c|c|c|c}
\hline \multicolumn{7}{c}{ Flow equaled or exceeded for indicated percentage of time (cubic feet per second) } \\
\hline 5 & 10 & 25 & 50 & 75 & 90 & 95 \\
\hline 15,400 & 12,700 & 7,830 & 4,550 & 2,160 & 1,140 & 711 \\
\hline
\end{tabular}


STATION NAME AND NUMBER.--02148300 Colonels Creek near Leesburg, SC

LOCATION.--Lat $34^{\circ} 00^{\prime 2} 5^{\prime \prime}$, long 80 $43^{\prime} 58^{\prime \prime}$ referenced to North American Datum of 1927, Richland County, SC, Hydrologic Unit 03050104, on SC Highway 262 bridge, $0.2 \mathrm{mi}$ above Jumping Run Creek, and $1.9 \mathrm{mi}$ southwest of Leesburg.

DRAINAGE AREA. $-40.2 \mathrm{mi}^{2}$.

PERIOD OF RECORD.-September 1966 to September 1980, and February 2004 to October 2007.

PERIOD OF ANALYSIS.-April 1967 to March 1980, and April 2004 to March 2007.

REMARKS. - No withdrawal or discharge data were available from the SCDHEC for this station. However, flow-duration curve analyses indicate that the effects of upstream point-source discharges may be substantial at lower flows.

\section{MAGNITUDE AND FREQUENCY OF ANNUAL FLOWS}

\begin{tabular}{|c|c|c|c|c|c|c|c|}
\hline \multirow[t]{2}{*}{$\begin{array}{l}\text { Recurrence } \\
\text { intervals } \\
\text { (years) }\end{array}$} & & & age $f$ & catec & cons & & \\
\hline & 1 & 3 & 7 & 14 & 30 & 60 & 90 \\
\hline 2 & 16 & 17 & 17 & 19 & 21 & 25 & 27 \\
\hline 5 & 11 & 11 & 12 & 13 & 15 & 18 & 20 \\
\hline 10 & 8.8 & 9.0 & 9.3 & 10 & 12 & 15 & 17 \\
\hline 20 & 7.1 & 7.2 & 7.5 & 8.2 & 9.9 & 13 & 15 \\
\hline
\end{tabular}

DURATION OF DAILY FLOW

Flow equaled or exceeded for indicated percentage of time

(cubic feet per second)

\begin{tabular}{ccccccc}
\hline 5 & 10 & 25 & 50 & 75 & 90 & 95 \\
\hline 97 & 76 & 51 & 35 & 24 & 17 & 13 \\
\hline
\end{tabular}


STATION NAME AND NUMBER.—02148315 Wateree River below Eastover, SC

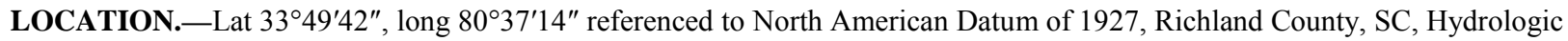
Unit 03050104 , on right bank, $1.3 \mathrm{mi}$ upstream from Southern Railway bridge, $1.8 \mathrm{mi}$ northeast of Wateree, 4.5 mi southeast of Eastover, and at river mile 10.8 .

DRAINAGE AREA. $-5,590 \mathrm{mi}^{2}$.

PERIOD OF RECORD.- July 1968 to current year.

PERIOD OF ANALYSIS.-July 1968 to March 2012.

REMARKS.-Flow regulated by powerplant at Wateree Reservoir (usable capacity, 2,794,000,000 $\mathrm{ft}^{3}$ ). Flow represents only that portion of the flow confined to the main channel, which is less than about $10,000 \mathrm{ft}^{3} / \mathrm{s}$. At times of high flow, bankfull capacity is exceeded in the intervening channel reach; therefore, daily mean flows greater than $10,000 \mathrm{ft}^{3} / \mathrm{s}$ are not determined and duration of daily flow analysis not made.

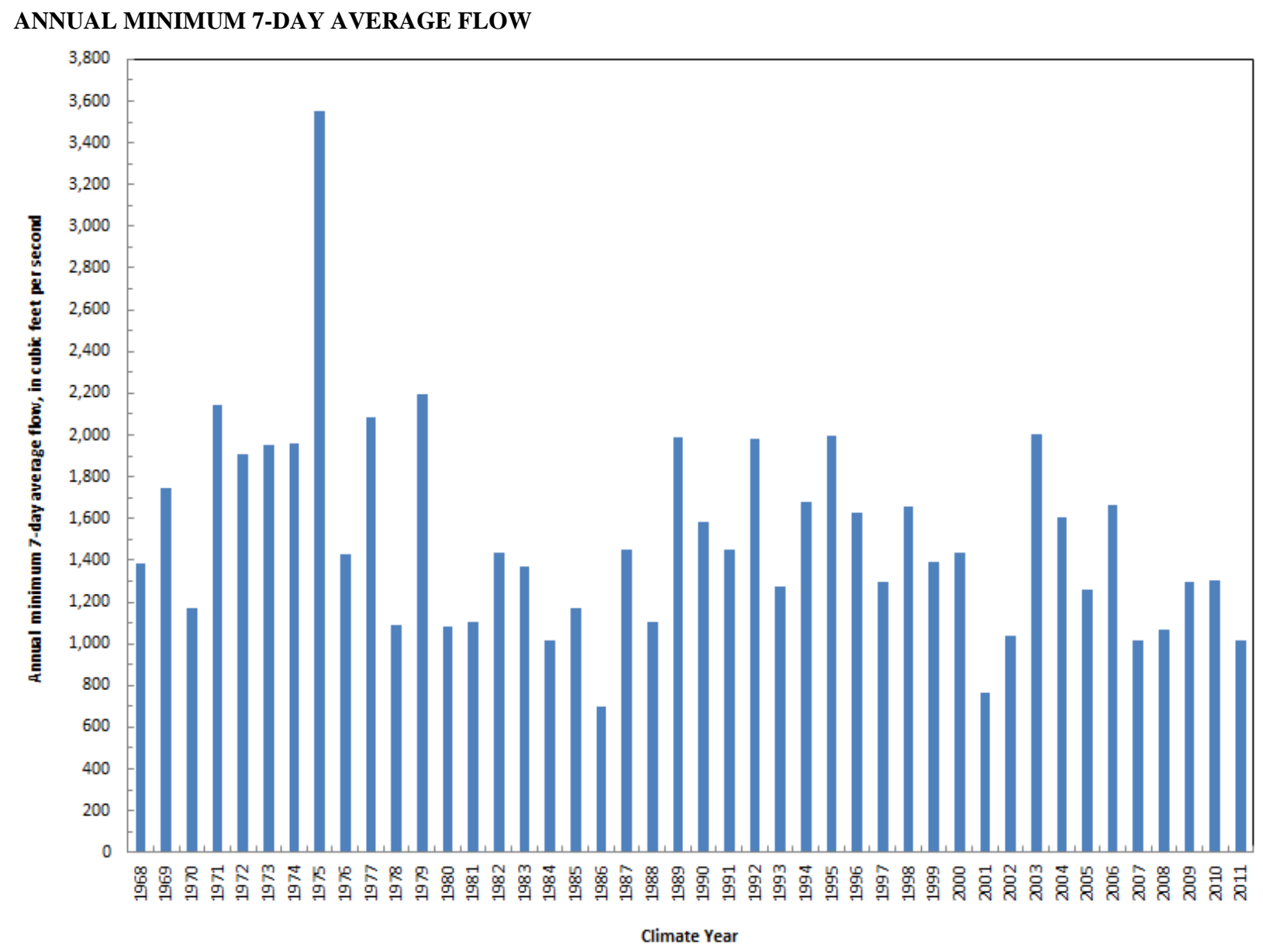

EXCEEDANCE PERCENTILES OF ANNUAL 7-DAY MINIMUM FLOWS

\begin{tabular}{c|c|c|c|c|c|c|r|r}
\hline \multicolumn{8}{c}{ Annual 7-day minimum flow exceeded for indicated percentiles (cubic feet per second) } \\
\hline 10 & 20 & 30 & 40 & 50 & 60 & 70 & 80 & 90 \\
\hline 2,170 & 1,960 & 1,670 & 1,580 & 1,430 & 1,300 & 1,210 & 1,090 & 1,020 \\
\hline
\end{tabular}


STATION NAME AND NUMBER.—02171500 Santee River near Pineville, SC

LOCATION.-Lat $33^{\circ} 27^{\prime} 15^{\prime \prime}$, long $80^{\circ} 08^{\prime} 30^{\prime \prime}$ referenced to North American Datum of 1927, Berkeley County, SC, Hydrologic Unit 03050112, on right bank 2.4 mi downstream from Lake Marion Dam, 3.0 mi upstream from Dead River, 6.7 mi west of Pineville, and at mile 85.0.

DRAINAGE AREA. $-14,700 \mathrm{mi}^{2}$.

PERIOD OF RECORD.-May 1942 to current year.

PERIOD OF ANALYSIS.-May 1942 to March 2012.

REMARKS.-Flow records for 1987-2004 water years are computed by utilization of a one-dimensional unsteady flow simulation model (Schaffranek and others, 1981). Flow completely regulated by Lake Marion. Water is diverted above the station from Lake Marion through the Diversion Canal into Lake Moultrie for power generation and navigation, and then discharged into the Cooper River basin and lower Santee River. During periods of incomplete gage-height record, values of daily mean flow from Lake Marion Hydro and Spillway were obtained from the South Carolina Public Service Authority. These values are shown as estimated daily flows. Seepage from north dike of Lake Marion Dam bypasses station through Little River.

\section{ANNUAL MINIMUM 7-DAY AVERAGE FLOW}

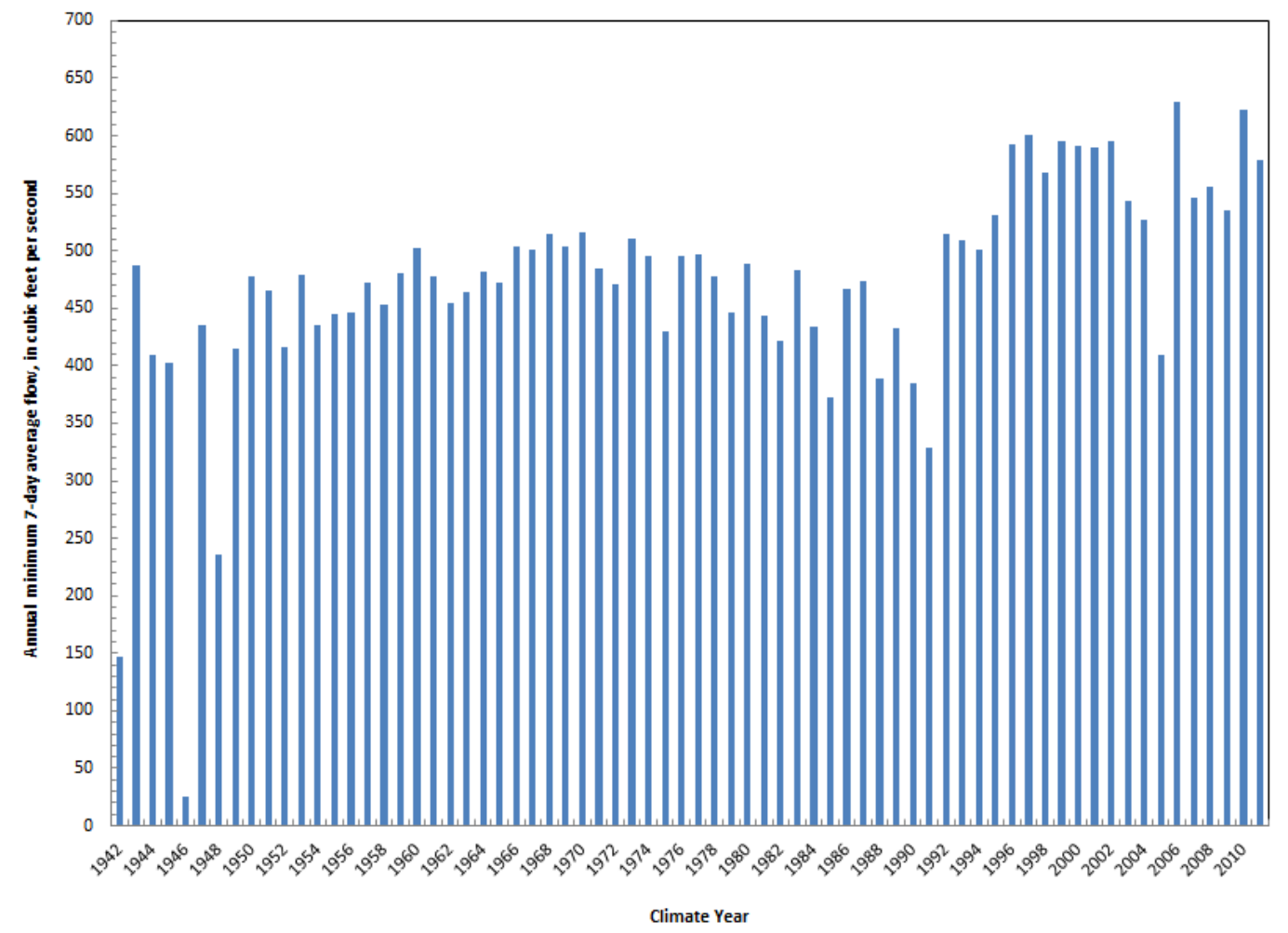

EXCEEDANCE PERCENTILES OF ANNUAL 7-DAY MINIMUM FLOWS

Annual 7-day minimum flow exceeded for indicated percentiles (cubic feet per second)

\begin{tabular}{c|c|c|c|c|c|c|c|c}
\hline \multicolumn{8}{c}{ Annual 7-day minimum flow exceeded for indicated percentiles (cubic feet per second) } \\
\hline 10 & 20 & 30 & 40 & 50 & 60 & 70 & 80 & 90 \\
\hline 591 & 534 & 507 & 496 & 480 & 471 & 446 & 430 & 390 \\
\hline
\end{tabular}

DURATION OF DAILY FLOW

\begin{tabular}{c|c|c|c|c|c|c}
\hline \multicolumn{7}{c}{ Flow equaled or exceeded for indicated percentage of time (cubic feet per second) } \\
\hline 5 & 10 & 25 & 50 & 75 & 90 & 95 \\
\hline 11,500 & 1,130 & 653 & 562 & 515 & 492 & 472 \\
\hline
\end{tabular}


STATION NAME AND NUMBER.--02171680 Wedboo Creek near Jamestown, SC

LOCATION.--Lat 3319'50", long 7948'10" referenced to North American Datum of 1983, Berkeley County, SC, Hydrologic Unit 03050112, at culvert on State Highway 45, 1.4 mi southeast of Alvin, 3.3 mi upstream from Santee River, and 7.5 mi northeast of Jamestown.

DRAINAGE AREA. $-17.4 \mathrm{mi}^{2}$.

PERIOD OF RECORD.-September 1966 to February 1972, February 1973 to September 1992.

PERIOD OF ANALYSIS.-April 1967 to March 1912.

REMARKS.-No known regulation or diversion upstream.

MAGNITUDE AND FREQUENCY OF ANNUAL FLOWS

\begin{tabular}{|c|c|c|c|c|c|c|c|}
\hline \multirow[t]{2}{*}{$\begin{array}{l}\text { Recurrence } \\
\text { intervals } \\
\text { (years) }\end{array}$} & & & age $\mathrm{fl}$ & licated & f conse & & \\
\hline & 1 & 3 & 7 & 14 & 30 & 60 & 90 \\
\hline 2 & 0.19 & 0.21 & 0.25 & 0.27 & 0.45 & 0.71 & 1.0 \\
\hline 5 & 0.0 & 0.0 & 0.0 & 0.02 & 0.13 & 0.27 & 0.45 \\
\hline 10 & 0.0 & 0.0 & 0.0 & 0.0 & 0.05 & 0.15 & 0.29 \\
\hline 20 & 0.0 & 0.0 & 0.0 & 0.0 & 0.0 & 0.09 & 0.20 \\
\hline 30 & 0.0 & 0.0 & 0.0 & 0.0 & 0.0 & 0.07 & 0.16 \\
\hline
\end{tabular}

DURATION OF DAILY FLOW

Flow equaled or exceeded for indicated percentage of time

(cubic feet per second)

\begin{tabular}{ccccccc}
\hline 5 & 10 & 25 & 50 & 75 & 90 & 95 \\
\hline 60 & 35 & 12 & 3.2 & 1.0 & 0.43 & 0.15 \\
\hline
\end{tabular}


STATION NAME AND NUMBER.—02171700 Santee River near Jamestown, SC

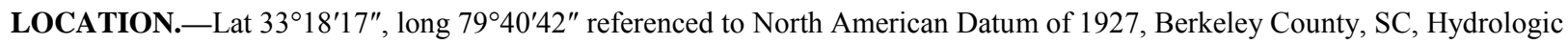
Unit 03050112, at downstream side of bridge on U.S. Highway 17A, 0.7 mi below Wittee Branch, 0.1 mi upstream from Seaboard Coastline Railroad, 1.5 mi northeast of Jamestown, and at river mile 36.4.

DRAINAGE AREA. $-10,750 \mathrm{mi}^{2}$.

PERIOD OF RECORD.- October 1986 to current year.

PERIOD OF ANALYSIS.-October 1986 to March 2012.

REMARKS.-Flow affected by regulation from Lake Marion and rediversion from St. Stephens powerplant. Astronomical tides cause cycles of approximately 24.8 hours at this site during periods of low to medium flow. During periods of higher flow, the tidal influence is overcome by basin runoff. October 2005 to current year, tidal effects were removed from unit value flows using the Godin filter. Daily mean flow computed from filtered values. Flow records for 1987-2000 water years were computed by utilization of a one-dimensional flow simulation model (Schaffranek and others, 1981).

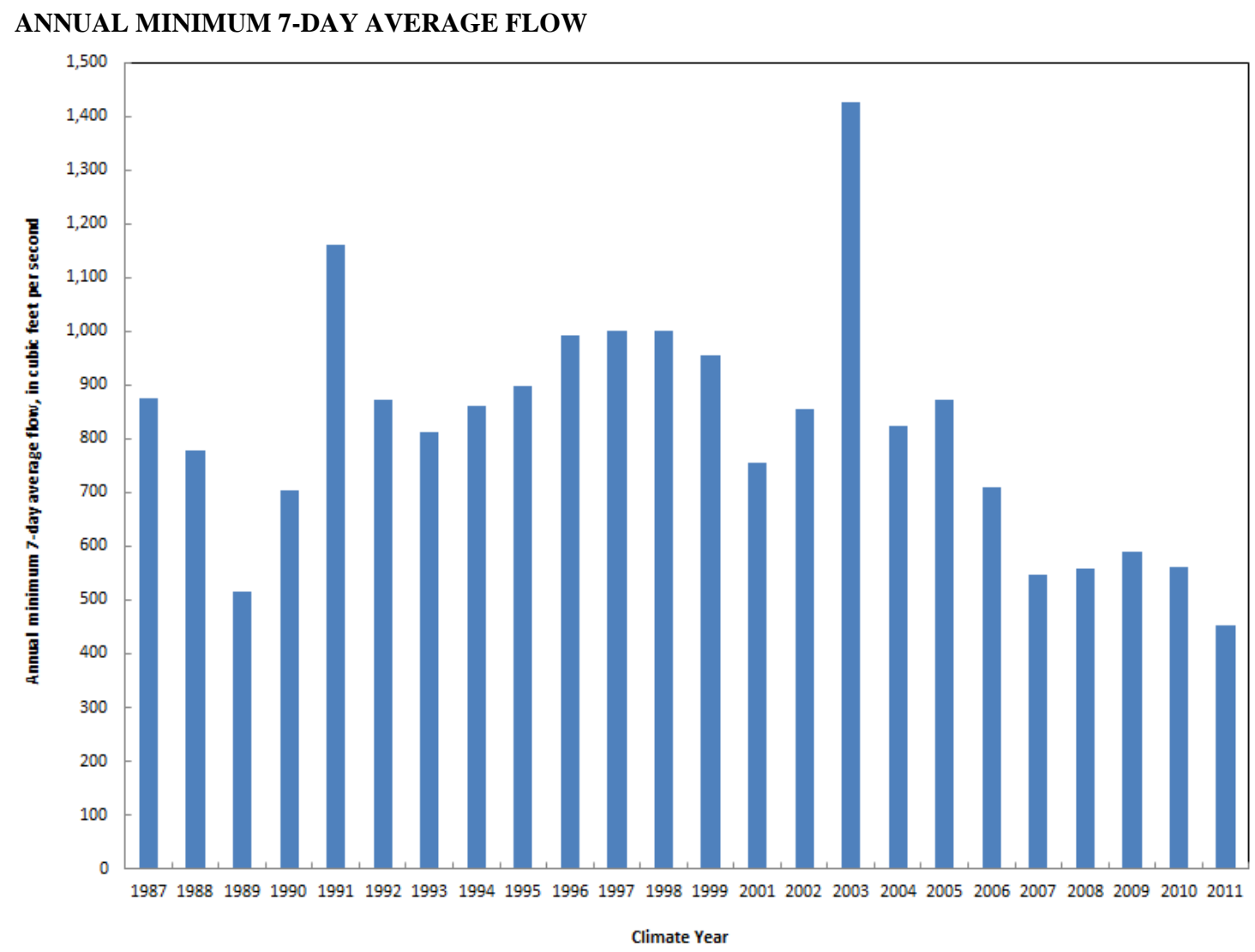

EXCEEDANCE PERCENTILES OF ANNUAL 7-DAY MINIMUM FLOWS

\begin{tabular}{c|c|c|c|c|c|c|c|c}
\hline \multicolumn{8}{c}{ Annual 7-day minimum flow exceed for indicated percentiles (cubic feet per second) } \\
\hline 10 & 20 & 30 & 40 & 50 & 60 & 70 & 80 & 90 \\
\hline 1,060 & 984 & 880 & 868 & 824 & 792 & 708 & 567 & 534 \\
\hline
\end{tabular}

DURATION OF DAILY FLOW

\begin{tabular}{c|c|c|c|c|c|c}
\hline \multicolumn{7}{c}{ Flow equaled or exceeded for indicated percentage of time (cubic feet per second) } \\
\hline 5 & 10 & 25 & 50 & 75 & 90 & 95 \\
\hline 27,500 & 24,000 & 14,700 & 4,600 & 1,040 & 782 & 655 \\
\hline
\end{tabular}


STATION NAME AND NUMBER.—02172002 Lake Moultrie Tailrace Canal at Moncks Corner, SC

LOCATION.—Lat 3312'54", long 7958'29" referenced to North American Datum of 1927, Berkeley County, SC, Hydrologic Unit 03050201, on upstream side of left fender pier, under U.S. Highway 52 bridge, 2.2 mi below Lake Moultrie Pinopolis Dam, and at river mile 45.8 .

DRAINAGE AREA.-14,800 $\mathrm{mi}^{2}$.

PERIOD OF RECORD.- October 1978 to September 2000 and October 2001 to current year.

PERIOD OF ANALYSIS.-October 1978 to September 2000 and October 2001 to March 2012.

REMARKS.-Discharge affected by regulation from Lake Moultrie Pinopolis Dam. Discharge records for the 1979-2001 water years computed by utilization of a one-dimensional unsteady flow simulation model (Schaffranek and others, 1981).

ANNUAL MINIMUM 7-DAY AVERAGE FLOW

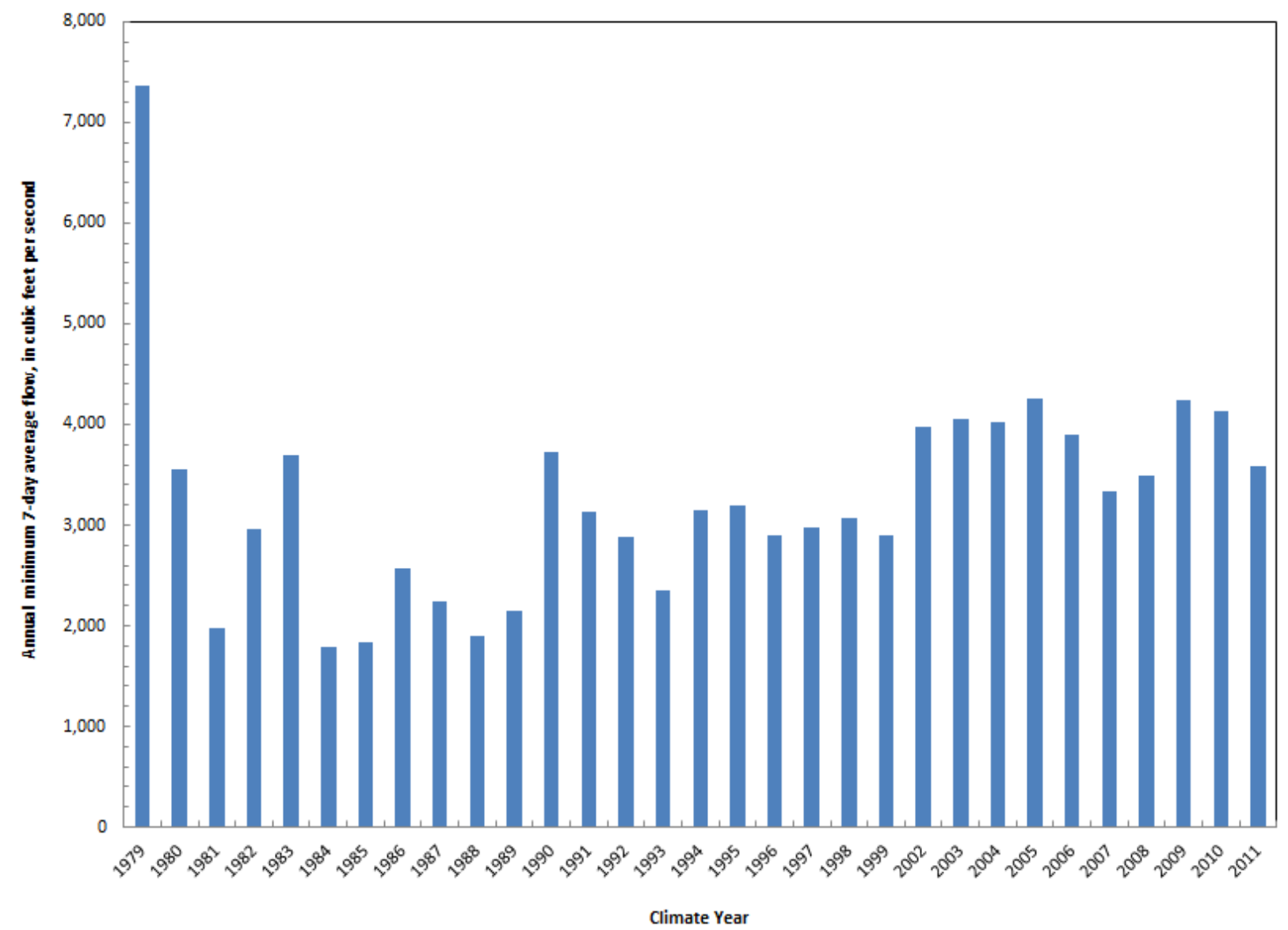

EXCEEDANCE PERCENTILES OF ANNUAL 7-DAY MINIMUM FLOWS

Annual 7-day minimum flow exceeded for indicated percentiles (cubic feet per second)

\begin{tabular}{c|c|c|c|c|c|c|c|c}
\hline \multicolumn{8}{c}{ Annual 7-day minimum flow exceeded for indicated percentiles (cubic feet per second) } \\
\hline 10 & 20 & 30 & 40 & 50 & 60 & 70 & 80 & 90 \\
\hline 4,320 & 4,020 & 3,700 & 3,450 & 3,140 & 2,960 & 2,890 & 2,360 & 1,980 \\
\hline
\end{tabular}

DURATION OF DAILY FLOW

Flow equaled or exceeded for indicated percentage of time (cubic feet per second)

\begin{tabular}{c|c|c|c|c|c|c}
\hline \multicolumn{2}{c}{ Flow equaled or exceeded for indicated percentage of time (cubic feet per second) } \\
\hline 5 & 10 & 25 & 50 & 75 & 90 & 95 \\
\hline 21,200 & 14,900 & 7,130 & 5,100 & 4,030 & 2,960 & 2,230 \\
\hline
\end{tabular}


For further information about this publication contact:

Director

USGS South Carolina Water Science Center

Stephenson Center, Suite 129

720 Gracern Road

Columbia, SC 29210-7651

Or visit the South Carolina Water Science Center Web site at $h$ ttp://sc.water.usgs.gov/

Prepared by the Raleigh Publishing Service Center 
